\title{
Lipophilic aroylhydrazone chelator HNTMB and its multiple effects on ovarian cancer cells
}

Kyu Kwang Kim ${ }^{1 \dagger}$, Thilo S Lange ${ }^{1,2 \dagger}$, Rakesh K Singh ${ }^{1}$, Laurent Brard ${ }^{1 *}$

\begin{abstract}
Background: Metal chelators have gained much attention as potential anti-cancer agents. However, the effects of chelators are often linked solely to their capacity to bind iron while the potential complexation of other trace metals has not been fully investigated. In present study, we evaluated the effects of various lipophilic aroylhydrazone chelators (AHC), including novel compound HNTMB, on various ovarian cancer cell lines (SKOV-3, OVCAR-3, NUTU-19).
\end{abstract}

Methods: Cell viability was analyzed via MTS cytotoxicity assays and NCl60 cancer cell growth screens. Apoptotic events were monitored via Western Blot analysis, fluorescence microscopy and TUNEL assay. FACS analysis was carried out to study Cell Cycle regulation and detection of intracellular Reactive Oxygen Species (ROS)

Results: HNTMB displayed high cytotoxicity (IC50 200-400 nM) compared to previously developed AHC (oVtBBH, HNtBBH, StBBH/206, HNTh2H/315, HNI/311; IC50 0.8-6 $\mu \mathrm{M}$ ) or cancer drug Deferoxamine, a hexadentate ironchelator (IC50 12-25 $\mu \mathrm{M}$ ). In a NCI60 cancer cell line screen HNTMB exhibited growth inhibitory effects with remarkable differences in specificity depending on the cell line studied (GI50 $10 \mathrm{nM}-2.4 \mu \mathrm{M}$ ). In SKOV-3 ovarian cancer cells HNTMB treatment led to chromatin fragmentation and activation of the extrinsic and intrinsic pathways of apoptosis with specific down-regulation of Bcl-2. HNTMB caused delayed cell cycle progression of SKOV-3 through G2/M phase arrest. HNTMB can chelate iron and copper of different oxidation states. Complexation with copper lead to high cytotoxicity via generation of reactive oxygen species (ROS) while treatment with iron complexes of the drug caused neither cytotoxicity nor increased ROS levels.

Conclusions: The present report suggests that both, non-complexed HNTMB as a chelator of intracellular tracemetals as well as a cytotoxic HNTMB/copper complex may be developed as potential therapeutic drugs in the treatment of ovarian and other solid tumors.

\section{Background}

The current treatment of a variety of tumors, including ovarian cancer, relies on organometallic platinum compounds. Ovarian cancer is the leading cause of death from gynecologic malignancies and ranks second among newly diagnosed gynecological cancers in the United States $[1,2]$. Although most women will initially respond to cytoreductive surgery and adjuvant paclitaxel-based and platinum-based chemotherapy, the majority will experience disease recurrence. While re-treatment with a platinum-based agent is possible for some women,

\footnotetext{
* Correspondence: Ibrard@wihri.org

† Contributed equally

'Molecular Therapeutics Laboratory, Program in Women's Oncology,

Department of Obstetrics and Gynecology, Women and Infants' Hospital of

RI, Alpert Medical School of Brown University, Providence, RI 02905, USA
}

overall response rates to second line chemotherapeutic agents are $15-30 \%$ and treatment of recurrent ovarian carcinoma is mainly directed at palliation [3-6]. Treatment strategies against tumors that developed resistance to standard chemotherapeutic agents, most notably platinum analogs, include non-platinum drugs with increased activity and response rates. Chelating drugs and chelator metal complexes are used for the prevention, diagnosis and treatment of cancer and chelating compounds with high affinity for iron or copper have been suggested as potential anti-tumor agents [7]. In previous studies the effects of chelating drugs were often linked solely to their capacity to complex iron while the potential complexation of other trace metals was not discussed or analyzed. One rationale for the anti-tumor activity of chelators is a higher Fe utilization

\section{Biomed Central}


by cancer cells and often elevated concentrations of trace metals, particularly of copper, in tumor patients [8-10].

Copper chelators such as D-penicillamine, trientine, tetrathiomolybdate are currently being used in the treatment of copper-overload disorders such as Wilson's disease. Copper complexes such as 8-hydroxyquinoline derivatives, pyrrolidine dithiocarbamate and clioquinol have been reported to be cytotoxic against cancer cells $[11,12]$. Copper is an essential cofactor for several extracellular and a multitude of intracellular enzymes and plays a pivotal role in cellular metabolism including energy production (cytochrome c oxidase), intracellular metal detoxification $(\mathrm{Cu}(\mathrm{I})$-glutathione-complex mediated metallothionein activity), iron detoxification (via ceruloplasmin), connective tissue formation (lysyl oxidase), and antioxidant defense system $[\mathrm{Cu} / \mathrm{Zn}$ superoxide dismutase (SOD)] against ROS [13,14]. ROS are tightly regulated in balance with cellular defensive antioxidants, such as catalase and SOD, and can participate in a multitude of cellular functions (e.g., signal transduction, platelet aggregation, immune system control, production of energy, phagocytosis, regulation of cellular growth, metabolism of xenobiotics) [15]. When generated excessively or when antioxidant function is disturbed, ROS can be cytotoxic through the oxidation of biomolecules (e.g., membranes, enzymes, carbohydrates, DNA). ROS have been implicated in cancer initiation, promotion and progression $[16,17]$. Cancer cells, presumably through mitochondria dysfunction and increased metabolism, generate a relatively high level of ROS and modulation of cellular ROS has been suggested as a strategy to selectively target cancer cells over normal cells $[18,19]$.

Iron chelators suggested as potential anti-tumor agents include deferoxamine (DFO) [20], deferiprone and deferasirox [21], tachpyridine [22], triapine [23] and O-trensox [24]. Iron is an essential component of many biological molecules including hemoglobin, myoglobin, ribonucleotide reductase (RR), cyclooxygenases, lipoxygenases, iron-sulfur proteins and hydroxylating enzymes $[22,25]$. An elevated level of iron has been linked to tumor risk [26] and the growth of neoplastic cells due to iron's catalytic effect on the formation of hydroxyl radicals and the suppression of host defense cell activity [27]. Neoplastic cells display an elevated expression of transferrin and its receptor as well as a high rate of iron internalization thereby justifying the development of chelating compounds for cancer therapy $[28,29]$. Accordingly, cancer cell death can be induced by depleting the intracellular iron pool as shown by $\mathrm{H}$-ferritin expression in ovarian cancer cells [30]. Targeting tumors with chelating agents in an attempt to alter cellular iron homeostasis or metabolism is a promising treatment approach [31].
The objective of the present study was to investigate the cytotoxic potential of 6- lipophilic aroylhydrazone chelators $(A H C s)$ in ovarian cancer cell lines. The present report suggests that newly designed compound $H N T M B$ displays cytotoxic properties superior to other $A H C s$ and to iron-chelator deferoxamine (included as control [20]). The mode of action in SKOV-3 ovarian cancer cells relies on the generation of ROS, caspase activation, Bcl-2 reduction, DNA degradation and G2/M phase cell cycle block. HNTMB when complexed with copper (I) or (II) but not with Fe(II) or (III) generates ROS and is highly cytotoxic. In summary, $H N T M B$ may serve as a potential therapeutic drug and an alternative to platinum drugs in the treatment of ovarian cancer.

\section{Methods}

\section{Synthesis and Materials}

Deferoxamine mesylate (DFO) was purchased from Sigma-Aldrich (St. Louis, MO). AHC compounds oVtBBH [32], HNtBBH [33], StBBH/206, HNTh2H/315 and $\mathrm{HNI} / 311[34,35]$ have been described previously. All $A H C s$ were synthesized as follows using the Schiff base condensation method. Briefly, each aldehyde was combined with an equimolar amount of the corresponding hydrazide in ethanol, stirred and refluxed. The resultant materials were collected by filtration to afford the desired product and were further purified by re-crystallization (HNI, StBBH and oVtBBH). The compounds were characterized by ${ }^{1} \mathrm{H}$ nuclear magnetic resonance spectroscopy $\left({ }^{1} \mathrm{H}\right.$ NMR) and mass spectrometry. Salicylaldehyde-4-tbutylbenzoyl hydrazone (StBBH/206): yield 92\%. Analytical data; ${ }^{1} \mathrm{H}$ NMR [dimethyl sulfoxide (DMSO) $-\mathrm{d}_{6}, \delta$ ] $12.0(1 \mathrm{H}), 11.3(1 \mathrm{H}), 8.6(1 \mathrm{H}), 7.9(2 \mathrm{H}), 7.5(3 \mathrm{H}), 7.3$ $(1 \mathrm{H}), 6.9(2 \mathrm{H}), 1.3(9 \mathrm{H})$. FAB-MS m/z (nitrobenzyl alcohol/NaI matrix) calculated for $\mathrm{C}_{18} \mathrm{H}_{20} \mathrm{~N}_{2} \mathrm{O}_{2}, 296.15\left[\mathrm{M}^{+}\right]$, found $319[\mathrm{M}+\mathrm{Na}]^{+}$. 2-hydroxy-1-naphthylaldehyde-4-tbutylbenzoyl hydrazone (HNtBBH): yield 71\%. Analytical data; ${ }^{1} \mathrm{H}$ NMR (DMSO-d $\left.{ }_{6}, \delta\right) 12.8(1 \mathrm{H}), 12.1(1 \mathrm{H}), 9.5$ $(1 \mathrm{H}), 8.2(1 \mathrm{H}), 7.9(4 \mathrm{H}), 7.6(3 \mathrm{H}), 7.4(1 \mathrm{H}), 7.2(1 \mathrm{H}), 1.3$ (9H). FAB-MS m/z (nitrobenzyl alcohol/NaI matrix) calculated for $\mathrm{C}_{22} \mathrm{H}_{22} \mathrm{~N}_{2} \mathrm{O}_{2}, 346.2\left[\mathrm{M}^{+}\right]$, found $369.2[\mathrm{M}$ $+\mathrm{Na}]^{+}$. 3-Methoxysalicylaldehyde-4-t-butylbenzoyl hydrazone (oVtBBH): yield 69\%. Analytical data; ${ }^{1} \mathrm{H}$ NMR $\left(\right.$ DMSO- $_{6}, \delta$; $) 12.0(1 \mathrm{H}), 11.09(1 \mathrm{H}), 8.6(1 \mathrm{H}), 7.9(2 \mathrm{H})$, $7.5(2 \mathrm{H}), 7.1(1 \mathrm{H}), 7.0(1 \mathrm{H}), 6.8(1 \mathrm{H}), 3.8(3 \mathrm{H}) 1.3(9 \mathrm{H})$. FAB-MS $\mathrm{m} / \mathrm{z}$ (nitrobenzyl alcohol/NaI matrix) calculated for $\mathrm{C}_{19} \mathrm{H}_{22} \mathrm{~N}_{2} \mathrm{O}_{3}, 326.2\left[\mathrm{M}^{+}\right]$, found $349.1[\mathrm{M}+\mathrm{Na}]^{+}$. 2hydroxy-1-naphthylaldehyde 3,4,5-trimethoxy-benzoylhydrazone $(H N T M B)$ : yield 67\%. ${ }^{1} \mathrm{H}$ NMR (DMSO- $\mathrm{d}_{6}, \delta$ ) $12.8(1 \mathrm{H}), 12.1(1 \mathrm{H}), 9.5(1 \mathrm{H}), 8.3(1 \mathrm{H}), 7.9(2 \mathrm{H}), 7.6$ $(1 \mathrm{H}), 7.3(4 \mathrm{H}), 3.9(6 \mathrm{H}), 3.8(3 \mathrm{H})$. FAB-MS m/z (nitrobenzyl alcohol/NaI matrix) calculated for $\mathrm{C}_{21} \mathrm{H}_{20} \mathrm{~N}_{2} \mathrm{O}_{5}$,

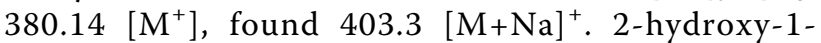
naphthylaldehyde isonicotinoyl hydrazone (HNI/311): 
$58 \%$ yielded. Analytical data; ${ }^{1} \mathrm{H}$ NMR (DMSO-d 6 , $\left.\delta\right) 12.5$ $(1 \mathrm{H}), 12.4(1 \mathrm{H}), 9.5(1 \mathrm{H}), 8.8(2 \mathrm{H}), 8.3(1 \mathrm{H}) 7.9(4 \mathrm{H}) 7.6$ $(1 \mathrm{H}) 7.4(1 \mathrm{H}) 7.2(1 \mathrm{H})$. ES-MS calcd for $\mathrm{C}_{17} \mathrm{H}_{13} \mathrm{~N}_{3} \mathrm{O}_{2}$, $291.1\left[\mathrm{M}^{+}\right]$, found $292.3[\mathrm{M}+1]^{+}$. 2-Hydroxy-1-naphthylaldehyde 2-thiophenecarboxy hydrazone (HNTh2H/ 315): yield 59.2\%. Analytical data; ${ }^{1} \mathrm{H}$ NMR (DMSO- $\mathrm{d}_{6}$, б) $12.6(1 \mathrm{H}), 12.2(1 \mathrm{H}), 9.4(1 \mathrm{H}), 8.3(1 \mathrm{H}), 7.9(4 \mathrm{H}), 7.6$ $(1 \mathrm{H}), 7.4(1 \mathrm{H}), 7.2(2 \mathrm{H})$. FAB-MS m/z (nitrobenzyl alcohol/NaI matrix) calculated for $\mathrm{C}_{16} \mathrm{H}_{12} \mathrm{~N}_{2} \mathrm{O}_{2} \mathrm{~S}, 296.06$ [M $\left.{ }^{+}\right]$, found $319.2[\mathrm{M}+\mathrm{Na}]^{+}$.

\section{Cell culture and cell viability assay}

SKOV-3 and OVCAR-3 (human ovarian adenocarcinomas) were purchased from ATCC (Manassas, VA). Cells were grown in Dulbecco's Modified Eagle's Medium (DMEM) supplemented with bovine calf serum or fetal calf serum (10\% for SKOV-3, 20\% for OVCAR-3). NUTU-19 rat epithelial ovarian cancer cells derived from Fischer 344 rats [36], a gift from Dr. G. Scott Rose (Section of Gynecologic Oncology, Cleveland Clinic Foundation, Cleveland, $\mathrm{OH}$ 44195, USA), were cultured in RPMI 1640 supplemented with $10 \%$ fetal bovine serum. Cells were cultured in the presence of 100 unit/ $\mathrm{ml}$ penicillin $\mathrm{G}$ and streptomycin at $37^{\circ} \mathrm{C}$ with $5 \%$ of $\mathrm{CO}_{2}$ in a humidified incubator. Viability of cell lines before and after drug treatment was determined by the CellTiter $96^{\circ}$ AQueous One Solution Assay (Promega Corp, Madison, WI) following the manufacturer's recommendations with suitable modifications. This colorimetric assay is based on the ability of mitochondria to reduce a substrate [MTS, 3-(4,5-dimethylthiazol-2yl)-5-(3-carboxymethoxyphenyl)-2-(4-sulfophenyl)-2Htetrazolium] into a soluble formazan product quantified by measuring the absorbance at $490 \mathrm{~nm}$. The resulting OD is directly proportional to the number of living cells [37]. Briefly, cells were seeded into a 96-well microtiter plate at 5,000 cells $/ 100 \mu \mathrm{l}$ per well in complete medium, allowed to attach at $37^{\circ} \mathrm{C}$ with $5 \%$ of $\mathrm{CO}_{2}$, in a humidified incubator and cells were treated with complete medium containing drugs originally dissolved in dimethyl sulfoxide (DMSO). Concentrations of the drugs are indicated for the respective experiment; the final concentration of the vehicle did not exceed more than $0.2 \%(\mathrm{v} / \mathrm{v})$. To determine the cytotoxicity when complexed with $\mathrm{Fe}(\mathrm{II}), \mathrm{Fe}(\mathrm{III}), \mathrm{Cu}(\mathrm{I})$ or $\mathrm{Cu}(\mathrm{II}), H N T M B$ was combined with the respective metal salt $\left(\mathrm{FeCl}_{2}\right.$, $\mathrm{FeCl}_{3}, \mathrm{CuCl}$ or $\left.\mathrm{CuCl}_{2}\right)(5 \mathrm{mM}$ stock solutions in DMSO). Complexes were formed by combining stock solutions of salts and chelator to $1000 \times$ the desired final assay concentration in DMSO, incubated at $37^{\circ} \mathrm{C}$ for 30 min before further dilution in complete medium for cell treatment. During the last $4 \mathrm{~h}$ of incubation at $37^{\circ} \mathrm{C}$ in a cell culture incubator, the MTS reagent was added at a 1:10 dilution to the medium. After the treatment period (as indicated) absorbance was measured at $490 \mathrm{~nm}$ in an ELISA plate reader (Thermo Labsystems, Waltham, MA). Experiments were performed in triplicates; data are expressed as the mean of the triplicate determinations $(\mathrm{X} \pm \mathrm{SD})$ of a representative experiment in \% of absorbance by samples with untreated cells $[=100 \%]$.

\section{$\mathrm{NCl} 60$ cancer cell line assay}

HNTMB was screened through the National Cancer Institute (NCI) Developmental Therapeutics Program (DTP) 60 human cancer cell line panel under the In Vitro Cell Line screening Project (IVCLSP). Briefly, cells (5,000 to 40,000 cells/well depending on the cell line studied) were inoculated into 96 well microtiter plates in $100 \mu$ complete RPMI1640 medium (5\% FBS and 2 $\mathrm{mM}$ L-glutamine) and incubated $24 \mathrm{~h}$ prior to addition of $H N T M B$. HNTMB was added and the plates were incubated at $37^{\circ} \mathrm{C}, 5 \% \mathrm{CO}_{2}, 95 \%$ air, and $100 \%$ relative humidity for an additional $48 \mathrm{~h}$. Upon the addition of $50 \mu \mathrm{l}$ of cold TCA (10\% TCA) the assay was terminated and incubated for $60 \mathrm{~min}$ at $4{ }^{\circ} \mathrm{C}$ to fix the cells. The supernatant was discarded, and the plates washed five times with water and air dried. Sulforhodamine B solution $(100 \mu \mathrm{l})$ at $0.4 \%(\mathrm{v} / \mathrm{v})$ in $1 \%$ acetic acid was added to each well, and plates incubated for $10 \mathrm{~min}$ at room temperature. After staining, unbound dye was removed by washing five times with $1 \%$ acetic acid and the plates were air dried. Bound stain was subsequently solubilized with $10 \mathrm{mM}$ trizma base, and the absorbance was read on an automated plate reader at a wavelength of 515 $\mathrm{nm}$. Using absorbance measurements [time zero $(\mathrm{Tz})$, control growth $(\mathrm{C})$, and test growth in the presence of drug at the drug concentration ( $\mathrm{Ti}$ )], the percentage growth was calculated. Percentage growth inhibition was calculated as: $[(\mathrm{Ti}-\mathrm{Tz}) /(\mathrm{C}-\mathrm{Tz})] \times 100$ for concentrations for which $\mathrm{Ti}>/=\mathrm{Tz},[(\mathrm{Ti}-\mathrm{Tz}) / \mathrm{Tz}] \times 100$ for concentrations for which $\mathrm{Ti}<\mathrm{Tz}$.

\section{Morphological Studies}

To assess morphological changes and chromatin condensation of SKOV-3 cells undergoing apoptosis following treatment with an iron-chelator, cells were stained with 4',6-diamidino-2-phenylindole (DAPI) and examined by fluorescence microscopy. Cells were seeded into compartments of 8 -well Lab-Tek ${ }^{\odot}$ II chamber slide (Nalge Nunc International, Naperville, IL), allowed to attach onto the slide and deprived of serum for $18 \mathrm{~h}$ prior to the incubation with $0.2 \mu \mathrm{M} \mathrm{HNTMB}$ for $24 \mathrm{~h}$. The cells were then washed with $1 \times \mathrm{PBS}$ with Calcium/ Magnesium (Invitrogen, Carlsbad, CA), fixed and permeablized by $2 \%$ paraformaldehyde solution with $0.2 \%$ Trition-X-100 in $1 \times$ PBS for $30 \mathrm{~min}$ at room temperature. The fixed cells were washed with $1 \times \mathrm{PBS}$. After removal of the upper chamber and silicone lining the 
cells were stained and mounted at room temperature with Vectashield ${ }^{\odot}$ Mounting Medium for Fluorescence with DAPI (Vector Laboratories). Once the excess amount of mounting medium was removed, the slide was examined under the fluorescence microscope (ECLIPSE TE 2000-E, Nikon Inc.).

\section{TUNEL Assay}

DNA fragmentation was detected using the DeadEndTM Fluorometric TUNEL System assay (Promega, Madison, WI) according to the manufacturer's recommendations. Cells $\left(4 \times 10^{5} /\right.$ well $)$ were seeded into 8 -well Lab-Tek ${ }^{\ominus} 11$ chamber slide (Nalge Nunc International, Naperville, IL), treated with $0.2 \mu \mathrm{M} H N T M B$ and the assay carried out as described previously [38]. Fluorescence of apoptotic cells (green; labeling of DNA nicks by fluorescein12-dUTP) and of chromatin (red; staining of chromatin with propidium iodide) was detected by fluorescence microscopy with an inverted microscope (Nikon Eclipse TE2000-E) and a $20 \times$ objective. Four randomly chosen microscopic fields were captured.

\section{Western Blot Analysis}

SKOV-3 cells $\left(1.5 \times 10^{6}\right.$ per dish) were seeded into 100 $\mathrm{mm}$ cell culture dishes allowed to attach overnight and serum-deprived for $18 \mathrm{~h}$ prior to the treatment under the condition as mentioned. Following treatment, cells were processed as described previously [39] in Cell Extraction Buffer (BioSource International, Inc., CA.) supplemented with protease inhibitor cocktail and phenylmethylsulfonyl fluoride (Sigma-Aldrich) according to the manufacturers' recommendations. Lysates were incubated at $4^{\circ} \mathrm{C}$ for $30 \mathrm{~min}$, sonicated (10 pulses $5 \mathrm{sec}$ ), centrifuged at $14,0000 \mathrm{~g}$ for $10 \mathrm{~min}$, and the protein concentration of the supernatant quantified (BioRad protein estimation kit, Hercules, CA). Protein electrophoresis was performed by using the NuPAGE ${ }^{\circ}$ Gel system (Invitrogen, Carlsbad, CA). Briefly, each lysate sample was mixed with LDS sample buffer and sample reducing buffer, incubated at $70^{\circ} \mathrm{C}$ for $10 \mathrm{~min}$, loaded (50 $\mathrm{\mu g} / \mathrm{sample})$ and separated by using Xcell SureLockTM mini-cell electrophoresis system (Invitrogen, Carlsbad, CA) on NuPAGE $4-12 \%$ Tris-Bis Gel in NuPAGE ${ }^{\bullet}$ MES SDS running buffer, transferred onto a PVDF membrane, blocked with 5\% nonfat dry milk in PBS-Tween and probed against various primary antibodies (dilution 1:1000, all from rabbit: PARP \#9541, XIAP \#2045, caspase-3 \#9661, caspase-7 \#9491, caspase-9 \#9501 (Asp330/37 kD fragment) or \#9505 (Asp315/35 kD fragment), caspase-8 \#9496, Bcl-xL \#2762, Bid \#2002; Cell Signaling Technologies, Danvers, MA), Bcl-2 \#551107 (BD Biosciences, San Jose, CA) or mouse betaactin \#sc-47778 or GAPDH \#sc-47724 antibody (Santacruz Biotechnology, Santa Cruz, CA; dilution 1:2000).
The bands were visualized using horseradish peroxidaseconjugated secondary antibody (Amersham-Pharmacia Biotech, Piscataway, NJ), followed by enhanced chemiluminescence (Upstate, Waltham, MA) and documented by autoradiography (F-Bx810 Film, Phenix, Hayward, CA).

\section{Cell cycle analysis}

Cell cycle analysis and quantification of apoptosis was carried out by flow cytometry. SKOV-3 $\left(1.0 \times 10^{6}\right)$ cells were seeded into $100 \mathrm{~mm}$ cell culture dishes, allowed to attach overnight and treated for $48 \mathrm{~h}$. At the end of the incubation period, cells were scraped off and transferred into $15 \mathrm{~mL}$ polypropylene centrifuge tubes along with the medium. Culture dishes were then washed once with $1 \times$ PBS, combined in the same tube. After centrifugation ( $250 \mathrm{~g}, 5 \mathrm{~min}$ ) cells were fixed by adding the ice-cold $70 \%$ ethanol solution gradually. The cells were stained in the buffer containing propidium iodide $(100 \mu \mathrm{g} / \mathrm{ml})$, sodium citrate $(1 \mathrm{mg} / \mathrm{ml})$ and Triton-X-100 $(3 \mu \mathrm{L} / \mathrm{ml})$ for $30 \mathrm{~min}$ at $37^{\circ} \mathrm{C}$ in the dark. Data was acquired on a BD FACSort flow cytometer using CellQuest software (BD Immunocytometry Systems, San Jose, CA) and analyzed by using ModFit LT software (Verity Software House, Inc., Topsham, ME). Ten thousand events were analyzed for each sample. Appropriate gating was used to select the single cell population SKOV-3 cells. The same gate was used on all samples, ensuring that measurements were conducted on a standardized cell population.

\section{Detection of intracellular Reactive Oxygen Species (ROS)}

Detection of intracellular ROS after SKOV-3 treatment with non-complexed or complexed $H N T M B$ (see Viability assay section) was measured by flow cytometry using carboxy-H2DCFDA dye (Invitrogen, Carlsbad, CA) as a probe. Carboxy-H2DCFDA is the acetylated form of a reduced fluorescein derivative that is cellpermeable and non-fluorescent. Once the acetate groups are cleaved by intracellular esterase activities, this compound becomes charged and better retained within the cell as compared to its lipophilic parent compound. In the presence of a cellular oxidant, the compound is oxidized and produces green-fluorescence that is detected by flow cytometry. This dye detects the following ROS: hydrogen peroxide $\left(\mathrm{H}_{2} \mathrm{O}_{2}\right)$, hydroxyl radical $\left(\mathrm{HO}^{*}\right)$, and peroxyl radical $\left(\mathrm{ROO}^{\circ}\right)$. SKOV-3 $\left(1.0 \times 10^{6}\right)$ cells were seeded into $100 \mathrm{~mm}$ cell culture dishes, allowed to attach overnight and treated under the condition as indicated. Following treatment, cells were further incubated with $25 \mu \mathrm{M}$ of carboxy-H2DCFDA for $30 \mathrm{~min}$ at $37^{\circ} \mathrm{C}$ with $5 \% \mathrm{CO}_{2}$ in a humidified incubator. Cells were harvested by trypsinization, centrifuged, then washed once with $\mathrm{PBS}$ and suspended in PBS. Data was acquired on a BD FACSort flow cytometer using 
CellQuest software (BD Immunocytometry Systems, San Jose, CA) and analyzed by using ModFit LT software (Verity Software House, Inc., Topsham, ME).

\section{Data Analysis}

Mean and standard deviation (SD) were calculated. Mean differences were determined by Student's t-test or determined by one-way ANOVA, using the Newman-Keuls test to account for multiple comparisons in post hoc analyses, except were indicated. Software used for these analyses was STATA 9.0 (StataCorp, College Station, TX.

\section{Results}

\section{Cytotoxic effect of aroylhydrazone chelators on ovarian} cancer cell lines

In an initial approach to analyze the potential of a variety of lipophilic iron-chelators of the $A H C$ class as anticancer drugs we performed viability assays employing two human platinum-resistant ovarian cancer cell lines (SKOV-3 and OVCAR-3) a rat ovarian cancer cell line (NUTU-19). The cytotoxic activity of each compound was measured by a colorimetric MTS assay (see Material and Methods), based on the reduction of a tetrazolium compound in active cell metabolism. DFO was included as a control compound. After cell treatment for $72 \mathrm{~h}$ all six $A H C$ tested showed more potent cytotoxic effects (Fig. 1) than DFO ( $\mathrm{IC}_{50}$ of $25 \mu \mathrm{M}$ for SKOV-3, $12 \mu \mathrm{M}$ for OVCAR-3 and NUTU-19) in all tested ovarian cancer cell lines. Novel compound $\operatorname{HNTMB}$ (Fig. 2), displayed superior cytotoxicity ( $72 \mathrm{~h}$ treatment, $\mathrm{IC}_{50}$ of 200 $\mathrm{nM}$ for SKOV-3, $400 \mathrm{nM}$ for OVCAR-3 and NUTU-19) (Fig. 1) when compared to all other $5 A H C$ tested (oVtBBH, HNtBBH, StBBH/206, HNTh2H/315, HNI/ 311 ) which were highly cytotoxic only at higher drug concentrations with $\mathrm{IC}_{50}$ values between $800 \mathrm{nM}$ and 6 $\mu \mathrm{M}$ depending on the cell line or compound studied.

\section{HNTMB displays differential effects on the growth of various human cancer cell lines}

The NCI-DTP performed a screen on HNTMB as a growth suppressor against a panel of 60 human cancer cell lines. The HNTMB concentrations representing 50\% growth inhibition $\left(\mathrm{GI}_{50}\right.$, Fig. $\left.3 \mathrm{~A}\right)$ were determined by using the dose-response growth curves of OVCAR ovarian cancer cell lines and other cancer cells (colon, lung, melanoma, leukemia, renal, prostate, central nervous system) against $H N T M B$ concentrations ranging from 10 $\mathrm{nM}$ to $100 \mu \mathrm{M})$ (Fig. 3A, B). HNTMB exhibited growth inhibitory effects against all cell lines tested with remarkable differences in specificity in a 240 fold range of $\mathrm{GI}_{50}$ values (between $10 \mathrm{nM}$ and $2.4 \mu \mathrm{M}$ depending on the cell line studied). HCC-2998 (colon) and MDA-MB-468 (breast) cancer cell lines appeared to be the most sensitive toward the $H N T M B$ treatments $\left(\mathrm{GI}_{50} \leq 10 \mathrm{nM}\right)$.
Relatively strong growth inhibitory effects (with $\mathrm{GI}_{50}$ values less than $50 \mathrm{nM}$ ) of $H N T M B$ were observed in 5 out of 6 leukemia cells (CCRF-CEM, HL-60(TB), K-562, RPMI-8226 and SR), 3 out of 9 non-small cell lung cancer cells (HOP-62, NCI-H460 and NCI-H522), 6 out of 7 colon cancer cells (HCC-2998, HCT-116, HCT-15, HT29, KM12 and SW-620), 2 out of 6 CNS cancer cells (SF-295 and SF-539), 4 out of 8 renal cancer cells (786-0, A498, CAKI-1 and RXF 393), 2 out of 2 prostate cancer (PC-3 and DU-145) and 5 out of 8 breast cancer cells (MCF-7, NCI/ADR-RES, HS 578T, MDA-MB-435 and MDA-MB-468). Among ovarian cancer OVCAR-3 (GI ${ }_{50}$ $=38 \mathrm{nM}$ ) displayed the highest sensitivity when compared to OVCAR-4, -5 , and -8 (Fig. 3C).

\section{Morphological changes, DNA fragmentation in SKOV-3 ovarian cancer cells after HNTMB treatment}

Cells undergoing apoptosis display characteristic changes in their morphology including plasma membrane blebbing, cell shrinkage, condensation and fragmentation of the nucleus and the formation of apoptotic bodies. In order to distinguish whether cell death in ovarian cancer cells upon HNTMB treatment is due to apoptosis, we first examined the morphologic changes of SKOV-3 cells after drug treatment. Nuclear staining using 4',6-diamidino-2-phenylindole (DAPI), a fluorescent DNA-binding dye, revealed that $\sim 40 \%$ of SKOV-3 cells treated with $H N T M B$ exhibited apparent nucleus condensation and fragmentation upon HNTMB treatment $(0.2 \mu \mathrm{M}, 24 \mathrm{~h})$ whereas the untreated control cells were not affected (Fig. 4A).

Another hallmark feature of cells undergoing apoptosis is often characterized by chromatin fragmentation e. g. cleavage of genomic DNA to 180-200 bp fragments. This event within individual cells can be analyzed by terminal deoxynucleotidyl transferase-mediated dUTP (conjugated to fluorescein) nick end labeling (TUNEL) [40]. SKOV-3 cells were treated with HNTMB and DNA fragmentation was visualized by fluorescence microscopy (Fig. 4B). To identify the entire population of SKOV-3 cells, the nuclei of cells were counterstained with propidium iodide (PI), a red fluorescence DNA intercalating dye. Treatment of SKOV-3 cells with $0.2 \mu \mathrm{M} \mathrm{HNTMB}$ for $24 \mathrm{~h}$ revealed an apoptotic population of $\sim 40 \%$ of cells with TUNEL positive nuclei (red/green channel overlay resulting in yellow color) whereas the untreated control cells were TUNEL-negative (Fig 4B).

\section{Induction of apoptosis in ovarian cancer cells after HTMB treatment}

To define the cellular response of SKOV-3 cells upon $H N T M B$ treatment we analyzed the activation of apoptotic markers by immunoblotting. Following HNTMB treatment for $24 \mathrm{~h}$ Western blotting confirmed the 


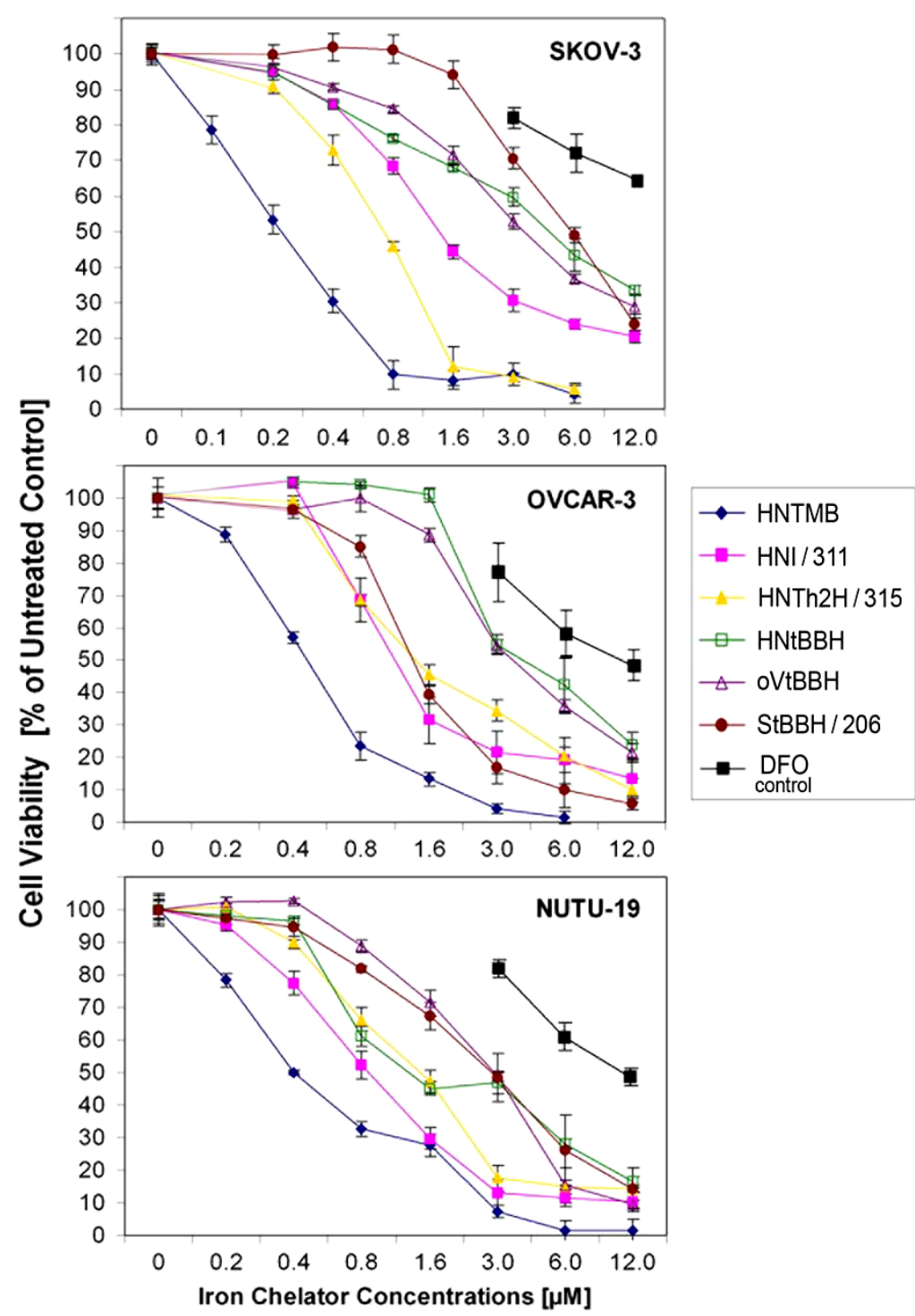

Figure 1 Cytotoxic effect of aroylhydrazone chelators $(A H C)$ in comparison to DFO in ovarian cancer cells. The cytotoxicity of chelators on human ovarian cancer cells (SKOV-3, OVCAR-3) and a rat ovarian cancer cells (NUTU-19) was evaluated by using the MTS viability assay as described (Materials and Methods). The cells were treated for $72 \mathrm{~h}$ with varying concentrations of various AHCs or DFO as control. HNTMB displayed the highest cytotoxicity $\left(\mathrm{IC}_{50}=0.2-0.8 \mu \mathrm{M}\right.$ depending on the cell line studied). Experiments were performed in triplicates; data are expressed as the mean of the triplicate determinations $(X \pm S D)$ of a representative experiment in \% cell viability of untreated cells [100\%].

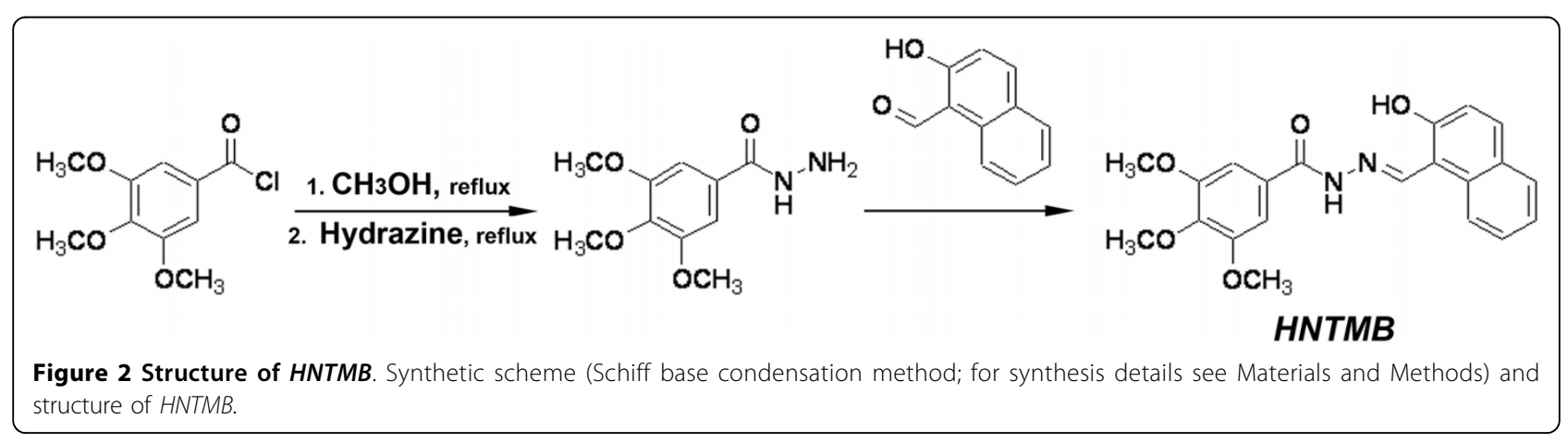




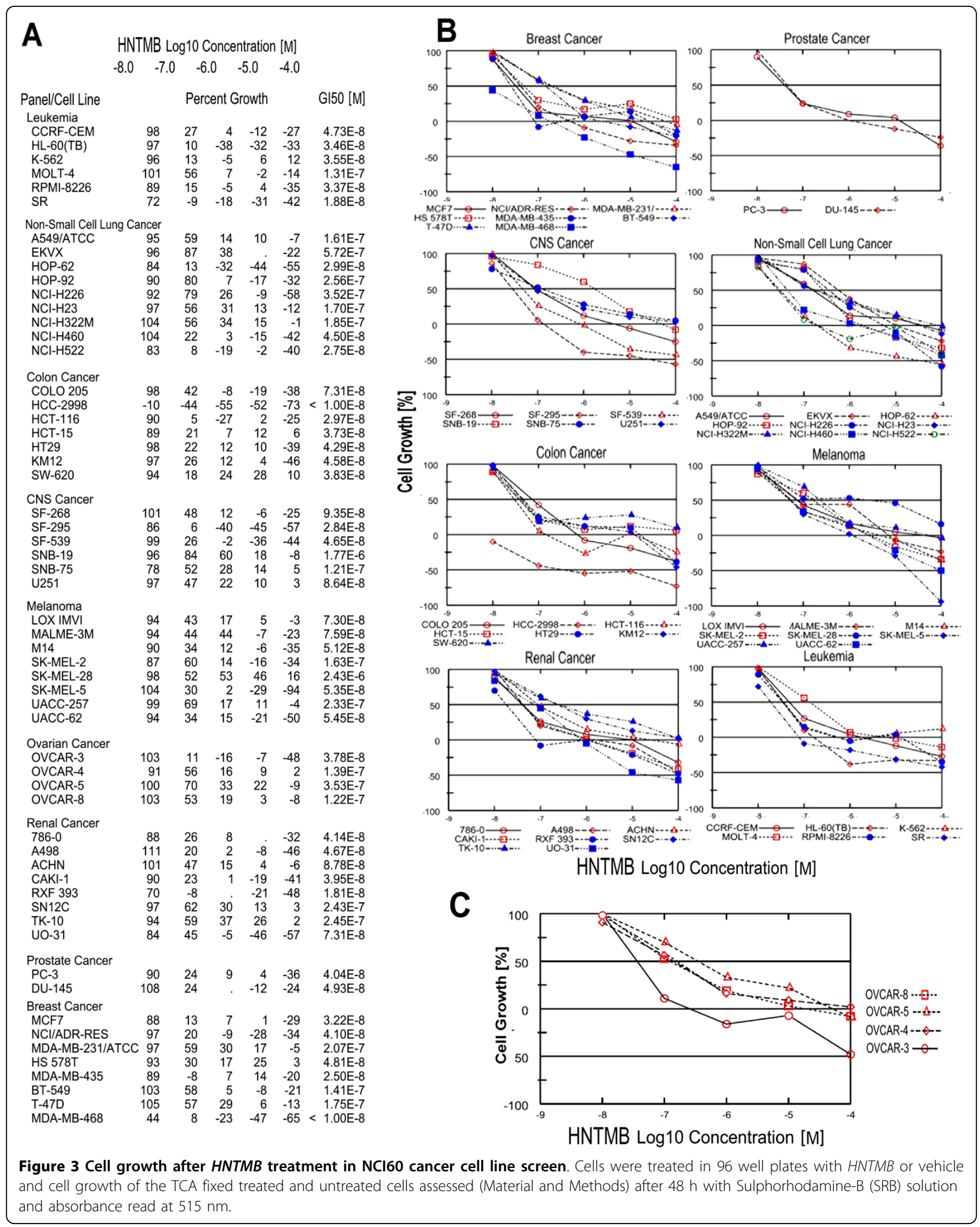


A
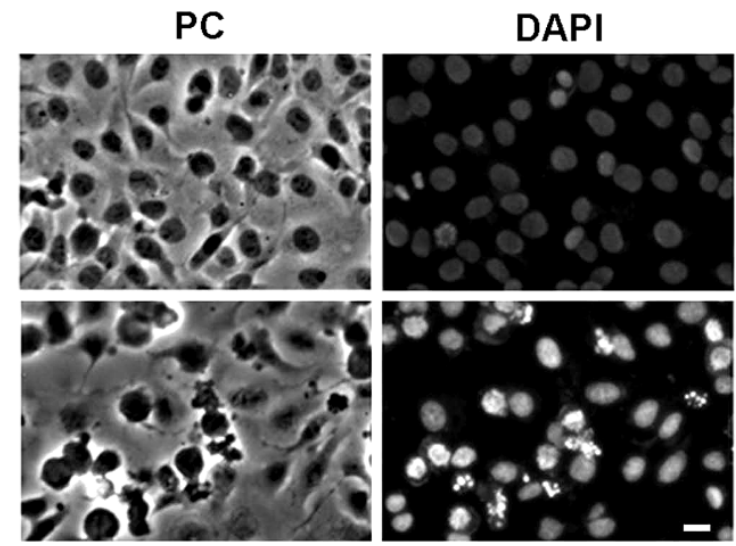

Untreated

HNTMB

$0.2 \mu \mathrm{M}$

B

$\mathrm{Pi}$

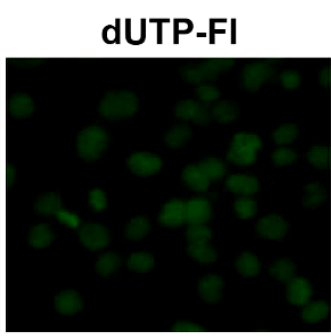

$\mathrm{Pi} /$ dUTP-FI
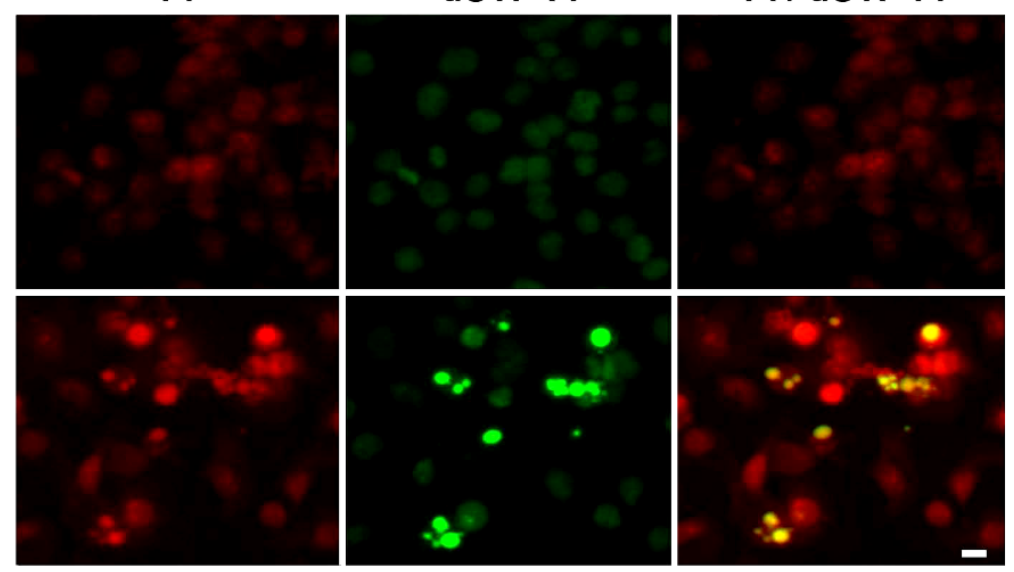

\section{Untreated}

HNTMB

$0.2 \mu \mathrm{M}$

Figure 4 Morphology changes and DNA fragmentation in ovarian cancer cells after HNTMB treatment. (A) Morphological changes following HNTMB treatment. SKOV-3 cells were treated for $24 \mathrm{~h}$ with $0.2 \mu \mathrm{M}$ HNTMB, fixed and stained with 4'-6-Diamidino-2-Phenylindole (DAPI) as described (Materials and Methods) before mounting. Microscopy was carried out (Nikon Eclipse TE2000-E inverted microscope, 20X objective) and representative images were taken. Bar $=10 \mu \mathrm{m}$. (B) TUNEL assay. SKOV-3 cells were treated with $0.2 \mu \mathrm{M}$ of HNTMB for $24 \mathrm{~h}$. Labeling of DNA nicks with fluorescein-12-dUTP and chromatin counterstaining with propidium iodide was carried out as described (Materials and Methods). Representative images were taken, apoptotic stain (FL-dUTP, green) and nuclear stain (Pi, red) overlaid; TUNEL positive nuclei due to DNA fragmentation appear as yellow areas. Bar $=10 \mu \mathrm{m}$.

activation of effector caspase-3, -7 and inactivation of PARP-1 (involved in DNA repair) in SKOV-3 cells (Fig. $5 \mathrm{~A})$. The cleavage of PARP is thought to represent the irreversible stage of cellular process in apoptosis events. In addition the expression of pro-survival marker XIAP, a direct inhibitor of executioner caspases such as caspase-3, was gradually down-regulated within 9 to $48 \mathrm{~h}$ following the HNTMB treatment (Fig. 5A).

Moreover, it was apparent that $H N T M B$ induced both major signaling pathways (intrinsic, extrinsic) described for programmed cell death. A prominent marker for the extrinsic pathway is activation of caspase- 8 which occurred following SKOV-3 treatment with HNTMB for $24 \mathrm{~h}$ (Fig. 5A). Features of the intrinsic pathway include the activation of pro-apoptotic members of the Bcl-2 family and/or down-regulation of anti-apoptotic Bcl-2 family members and cleavage/activation of caspase- 9 which also occurred in SKOV-3 following $24 \mathrm{~h}$ of HNTMB treatment (Fig. 5A). Caspase-9 was activated by a feedback mechanism through cleavage (at Asp330) via caspase-3 yielding a large fragment, p37, (Fig. 5A) and through apoptosome-dependent self-cleavage (at Asp315) yielding fragment p35 (data not shown). Interestingly, down-regulation of anti-apoptotic Bcl-2 but not Bcl-xL was observed (Fig. 5B). In addition, no change in the expression of full-length Bid (22 kD) or truncatedBid (also known to trigger mitochondrial signaling) was observed (Fig. 5B).

\section{HNTMB treatment induces SKOV-3 cell cycle arrest in G2/} $M$ phase

As described in the previous sections, $H N T M B$ is a cytotoxic agent which activates apoptotic processes in SKOV-3 ovarian cancer cells. To investigate if HNTMB 
A

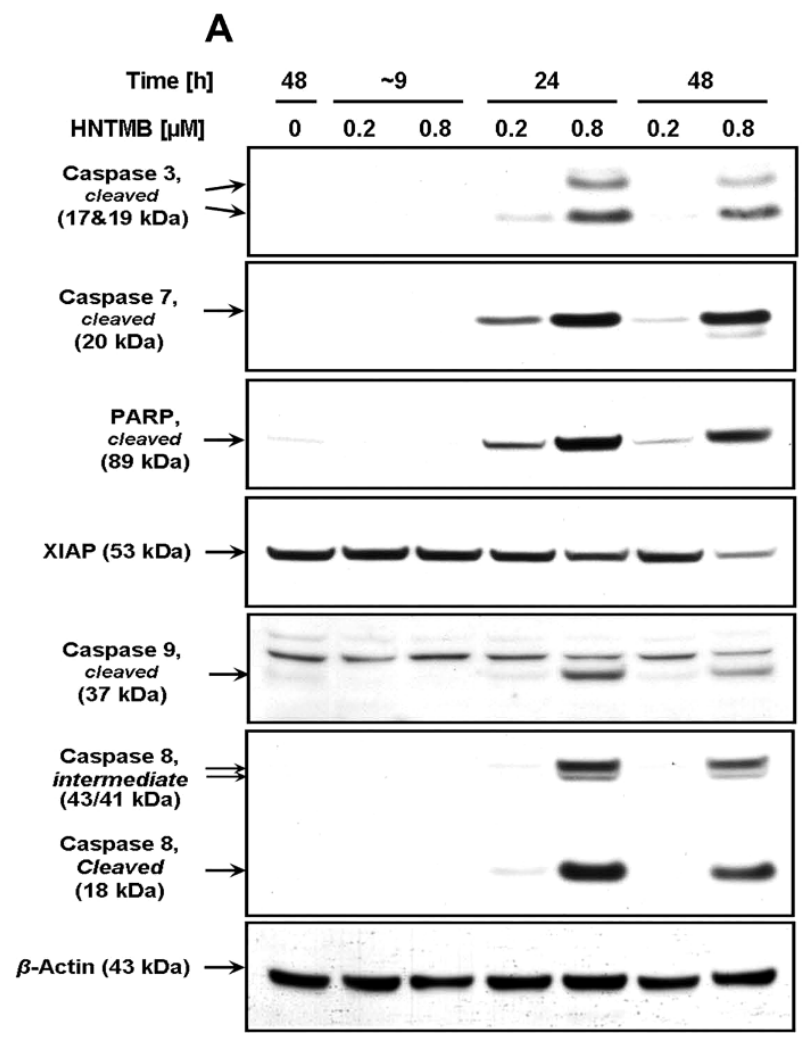

B

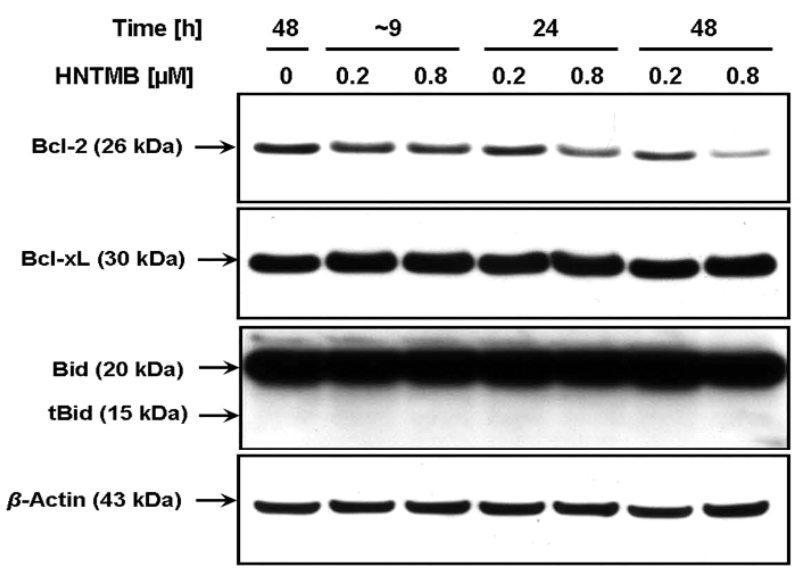

Figure 5 Expression of apoptotic markers in SKOV-3 cells after HNTMB chelator treatment. SKOV-3 cells were treated with HMTNB (0, 0.2, $0.8 \mu \mathrm{M})$ for 9,24 or $48 \mathrm{~h}$. PAGE and Western blot analysis of cell lysates were carried out as described (Materials and Methods). A representative experiment is shown. Immunoblotting was carried out with primary antibodies against PARP, caspase-3, caspase-7, caspase-8, caspase-9, Bcl-2,

Bid, and XIAP. As an internal standard for equal loading blots were probed with an anti- $\beta$-Actin antibody.

affects the proliferation of SKOV-3 cells (particularly at drug concentrations when viability is only partially reduced) we analyzed the cell cycle distribution of SKOV-3 cells in response to $H N T M B$ treatment by FACS.

While only $4.4 \%$ of untreated cells were present in the G2/M sub-population, HNTMB treatment for $48 \mathrm{~h}$ led to a dose-dependent $\mathrm{G} 2 / \mathrm{M}$ phase arrest (Fig. 6A) with $23.8 \%$ cells (at $0.3 \mu \mathrm{M}$ drug concentration) and $67.3 \%$ cells (at $0.6 \mu \mathrm{M}$ ) in G2/M (Fig. 6B). Accordingly, the cell sub-population in G0/G1 phase, when compared to untreated cells $(78.7 \%)$, was reduced to $42.7 \%(0.3 \mu \mathrm{M}$ $H N T M B)$ and $8.2 \%(0.6 \mu \mathrm{M} H N T M B)$, respectively. In addition, FACS analysis after HNTMB treatment revealed an increase in the count of apoptotic subdiploidal/2n cells (sub-G0/G1, Fig. 6B) in a dose-dependent manner. Treatment of this unsynchronized cell culture led to a delayed progression of cells through Sphase $(16.9 \%$ in untreated SKOV-3) which was apparent at $0.3 \mu \mathrm{M} \mathrm{HNTMB}$ (33.5\% in S-phase). At the highly cytotoxic concentration of $0.6 \mu \mathrm{M}$ drug we observed a loss of cells in culture due to cell shrinkage and disintegration, an increase of apoptotic sub-diploidal $/ 2 \mathrm{n}$ cells $(34.3 \%)$ while $24.5 \%$ of the cells were in S-phase.

\section{HNTMB/Copper complexes but not HNTMB/Iron} complexes mediate cytotoxicity and ROS generation

$H N T M B$ as a chelator has the potential to bind various trace metals present in human tissues, cancer, serum, plasma and cell lines, such as iron, copper, zinc, magnesium, cadmium. In a viability assay we determined the cytotoxicity of $H N T M B$ when complexed with $\mathrm{Fe}(\mathrm{II}), \mathrm{Fe}$ (III), $\mathrm{Cu}(\mathrm{I})$ or $\mathrm{Cu}(\mathrm{II})$. Complexes were formed by combining stock solutions of $H N T M B$ and respective metal salts $\left(\mathrm{FeCl}_{2}, \mathrm{FeCl}_{3}, \mathrm{CuCl}\right.$ or $\left.\mathrm{CuCl}_{2}\right)$ to $1000 \times$ the desired final assay concentration in DMSO, followed by incubation at $37^{\circ} \mathrm{C}$ for $30 \mathrm{~min}$ before further dilution in complete medium for cell treatment.

The $\mathrm{IC}_{50}$ following $48 \mathrm{~h}$ treatment of SKOV-3 with non-complexed $H N T M B$ is approximately $0.4 \mu \mathrm{M}$. Fig. $7 \mathrm{~A}$ shows that at this drug concentration cell viability was reduced to $54.8 \%$ of the untreated controls. Previously, in a publication on the chemotherapeutic activity of Salophene complexes we showed that Fe[III] alone does not display significant cytotoxic effects in SKOV-3 


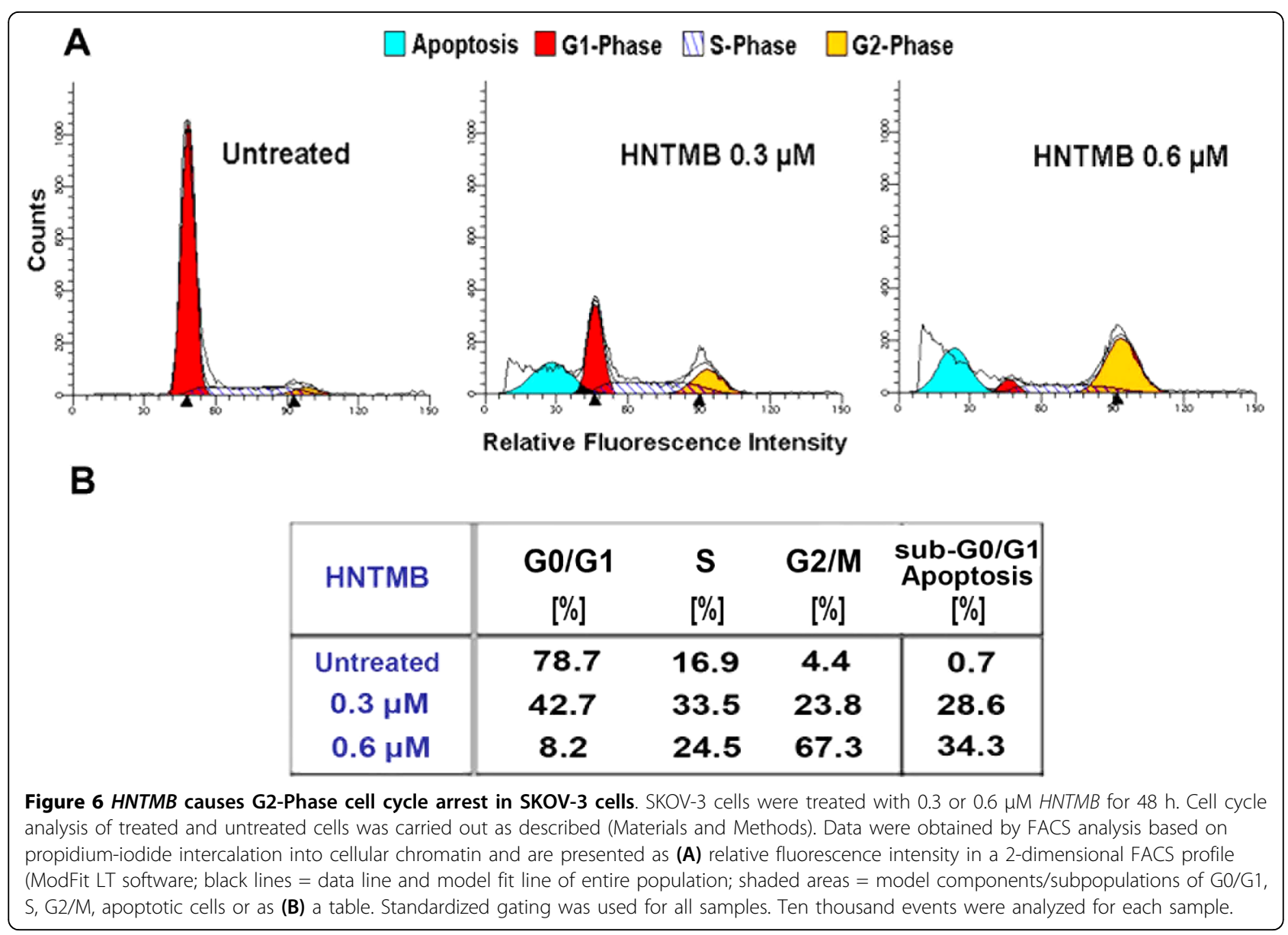

cells at or below the concentrations of $60 \mu \mathrm{M}$, whereas $\mathrm{Cu}[\mathrm{II}]$ displays partial cytotoxicity (33\% of cells) at a concentration of $60 \mu \mathrm{M}$ but not $\leq 30 \mu \mathrm{M}$ [41]. Accordingly, treatment of SKOV-3 cells with $\mathrm{FeCl}_{2}, \mathrm{FeCl}_{3}$, $\mathrm{CuCl}$ or $\mathrm{CuCl}_{2}$ at concentrations of $1.6 \mu \mathrm{M}$ did not affect cell viability nor did $0.4 \mu \mathrm{M} H N T M B$ when complexed with $\mathrm{Fe}(\mathrm{II})$ or $\mathrm{Fe}(\mathrm{III})$. In contrast, $0.4 \mu \mathrm{M}$ $H N T M B$ when complexed with $\mathrm{Cu}(\mathrm{I})$ or $\mathrm{Cu}(\mathrm{II})$ was highly cytotoxic to the cells (Fig. 7A). When HNTMB was chelated with $\mathrm{Cu}$ (II) (at $1000 \times$ the desired assay concentration and prior to 1000 fold dilution in complete medium for treatment), cell viability was reduced 2-fold (26.4\%; $\mathrm{Cu}(\mathrm{II}) / H N T M B$ 1.6/0.4 $\mu \mathrm{M})$ as compared to non-complexed HNTMB (54.8\%). Using a $\mathrm{Cu}(\mathrm{I}) /$ $H N T M B$ complex $(1.6 / 0.4 \mu \mathrm{M})$ viability was reduced to $31.9 \%$. When chelation was carried out in the presence of $\mathrm{Cu}$ salts cytotoxicity was still higher $(43.3 \%$ for $\mathrm{Cu}$ (II)/HNTMB $0.8 / 0.4 \mu \mathrm{M}$ and $40.7 \%$ for $\mathrm{Cu}(\mathrm{I}) / H N T M B$ $1.6 / 0.4 \mu \mathrm{M})$ compared to non-complexed HNTMB. These results indicated that (i) we efficiently achieved $H N T M B$-metal complexation under the experimental conditions described (Material and Methods), (ii) $H N T M B$ pre-chelated with iron did not exert cytotoxic effects in SKOV-3 cells, (iii) no significant dissociation of these pre-formed complexes occurred under our experimental conditions because measured cytotoxicities were, for example, less than [in the case of Fe (II or III)] that for non-complexed $H N T M B$, and iv). Pre-Cu chelated $H N T M B$ was more cytotoxic than non-complexed HNTMB.

Next, we carried out $H N T M B$ complex formation under competing conditions for $\mathrm{Fe}$ and $\mathrm{Cu}$-salts (Fig. $7 \mathrm{~B}$; group 1) prior to performing cell viability assays or we combined pre-formed $\mathrm{Fe} /-$ and $\mathrm{Cu} / H N T M B$ complexes and measured their effects in the viability assay (Fig. 7B; group 2.). When $\mathrm{Fe}(\mathrm{II})$ - and $\mathrm{Cu}(\mathrm{II})$-salts were incubated together with $H N T M B$ prior to treatment (Fig. 7B, group 1), cell viability was reduced to $71.3 \%$ (Fe(II)/Cu(II)/HNTMB) compared to $104.4 \%$ for $\mathrm{Fe}(\mathrm{II}) /$ $H N T M B, 43.3 \%$ for $\mathrm{Cu}(\mathrm{II}) / H N T M B$ and $54.8 \%$ for noncomplexed $H N T M B$ (Fig. 7A). These data suggest that $H N T M B$, under our experimental conditions, had a similar affinity for Fe salts and $\mathrm{Cu}$ salts. Accordingly, when $\mathrm{Fe}(\mathrm{III})$ and $\mathrm{Cu}(\mathrm{II})$ were incubated together with $H N T M B$ prior to treatment viability was reduced to $68.8 \%$ for $\mathrm{Fe}(\mathrm{III}) / \mathrm{Cu}(\mathrm{II}) / H N T M B)$ compared to $96.9 \%$ 

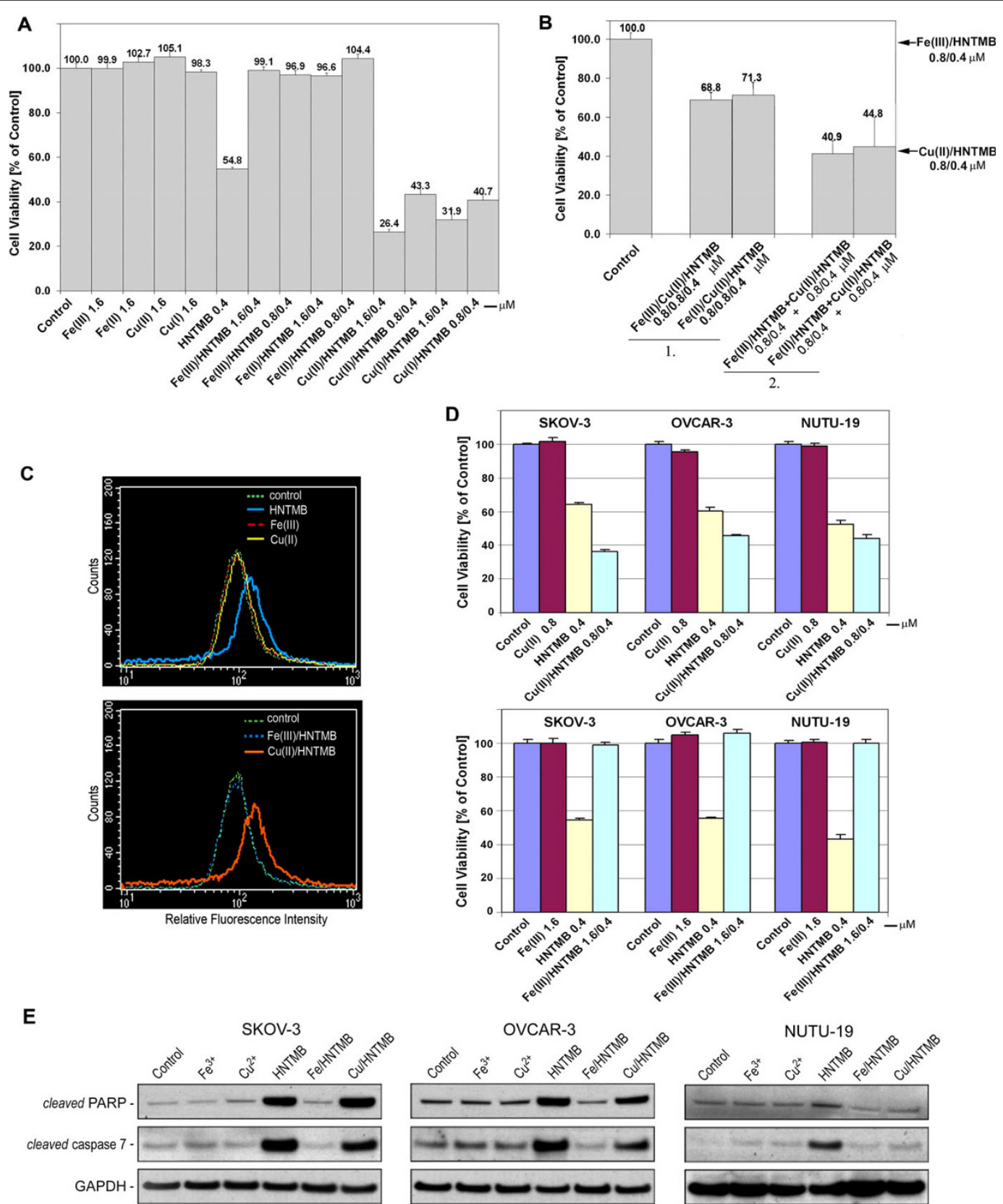

Figure 7 Effect of iron/HNTMB and copper/HNTMB complexes on viability, ROS generation, and induction of apoptosis. (A) Cytotoxicity of HNTMB in SKOV-3 cells when complexed with Fe(II), Fe(III), $\mathrm{Cu}(\mathrm{I})$ or $\mathrm{Cu}(\mathrm{II})$ Complexes were formed by combining HNTMB and respective metal salts to $1000 \times[0.4 \mathrm{mM}$ HNTMB; 1.6 or $0.8 \mathrm{mM} \mathrm{Fe}(\mathrm{II}), \mathrm{Fe}(\mathrm{III}), \mathrm{Cu}(\mathrm{I})$ or $\mathrm{Cu}(\mathrm{II})]$ the assay concentration before addition (diluted 1:1000) to the cells (48 $\mathrm{h}$ treatment). As controls served cells left untreated, incubated with metal salts $(1.6 \mu \mathrm{M})$ or non-complexed HNTMB (at IC 50 concentration, 0.4

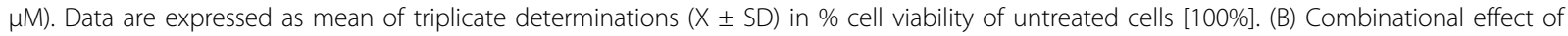
HNTMB iron- and copper-complexes on cell viability in SKOV-3 cells. Group 1: HNTMB complex formation was performed under competing conditions for Fe and Cu-chelation at 1000x the desired assay concentration before addition of this mixture (diluted 1:1000) to the cells (48 $\mathrm{h}$ treatment). Group 2: Stock solutions (1000x) of pre-formed complexes of Fe(II) or Fe(III)/- and $\mathrm{Cu}(\mathrm{II}) / H N T N B$ were individually diluted before simultaneous addition to the cells (48 $\mathrm{h}$ treatment). (C) Detection of intracellular ROS in SKOV-3 cells Generation of ROS following treatment with non-complexed or complexed HNTMB was measured by flow cytometry. Data are presented as relative-fluorescence-intensity in a 2-dimensional FACS profile (standardized gating; 10.000 events). (D) Effect of HNTMB complexation with Fe(III) or Cu(II) on the viability of various ovarian cancer cell lines SKOV-3, OVCAR-3 or NUTU-19 cells were treated with $0.4 \mu \mathrm{M}$ non-complexed or complexed (Cu(II)-upper panel; Fe(III)-lower panel) HNTMB for $48 \mathrm{~h}$ and the assay carried out. (E) Effect of HNTMB complexation with $\mathrm{Fe}(\mathrm{III})$ or $\mathrm{Cu}(\mathrm{II})$ on expression of apoptotic markers in various ovarian cancer cell lines SKOV-3, OVCAR-3 or NUTU-19 cells were treated with $0.4 \mu \mathrm{M}$ non-complexed or complexed HNTMB for 48 h. Western blot analysis of cell lysates was carried with primary antibodies against PARP-1, caspase-7 and GAPDH (control). 
for $\mathrm{Fe}(\mathrm{III}) / H N T M B, 43.3 \%$ for $\mathrm{Cu}(\mathrm{II}) / H N T M B$ and $54.8 \%$ for non-complexed HNTMB (Fig. 7A).

When $\mathrm{Fe}$ or $\mathrm{Cu}$ complexes were pre-formed $(0.8 \mu \mathrm{M}$ metal, $0.4 \mu \mathrm{M} H N T M B$ ) and added individually to the cells (Fig. 7B, group 2), cell viability was $40.9 \%$ for $\mathrm{Fe}$ (III) $/ H N T M B+\mathrm{Cu}(\mathrm{II}) / H N T M B$ and $44.8 \%$ for $\mathrm{Fe}(\mathrm{II}) /$ $H N T M B+\mathrm{Cu}(\mathrm{II}) / H N T M B)$ instead of $43.3 \%$ viability when the same concentration of $\mathrm{Cu}(\mathrm{II}) / H N T M B$ alone was used (Fig. 7B, arrow). This suggested that the cytotoxicity exerted by a copper/HNTMB complex was not altered and that no additional cytotoxic effect through co-treatment with an iron/HNTMB complex was achieved.

One potential strategy suggested to treat cancer is to generate an excess amount of ROS in tumor tissue to induce necrosis and/or apoptosis. We determined if SKOV-3 following treatment with non-complexed $H N T M B$ or $\mathrm{Cu} / \mathrm{Fe}$ complexed-HNTMB lead to the generation of ROS. These species were detected via Carboxy-H2DCFDA, which is a fluorescein derivative that is cell-permeable and non-fluorescent. In the presence of a cellular oxidant, the molecule is oxidized and produces green-fluorescence that is detected by flow cytometry. As shown in Fig. 7C, ROS generation in SKOV-3 cells remained unchanged as compared to untreated controls when either $\mathrm{Fe}(\mathrm{III}) / H N T M B$ complex $(0.8 / 0.4 \mu \mathrm{M})$ or $\mathrm{FeCl}_{3}$ and $\mathrm{CuCl}_{2}$ metal salts $(0.8 \mu \mathrm{M})$ were used. However, ROS generation increased (shift in relative fluorescence intensity, Fig. 7C) following treatment of cells for $20 \mathrm{~h}$ with either $0.4 \mu \mathrm{M}$ non-complexed $H N T M B$ (upper panel) or $\mathrm{Cu}(\mathrm{II}) / H N T M B(0.8 / 0.4 \mu \mathrm{M}$; lower panel) which correlated with a reduction in cell viability by these compounds at the same concentration (Fig. 7A).

To rule out that the effects of HNTMB complexation are cell type specific we compared the cytotoxic effects (Fig. 7D) and induction of apoptotic markers (Fig. 7E) by $H N T M B$ when complexed with $\mathrm{Fe}(\mathrm{III})$ or $\mathrm{Cu}(\mathrm{II})$ in three different ovarian cancer cell lines.

Human platinum resistant OVCAR-3 cells as well as rat NUTU-19 displayed a similar response profile as SKOV-3 and treatment of these cell lines with $\mathrm{CuCl}_{2}$ at concentrations of $0.8 \mu \mathrm{M}$ did not affect cell viability. In contrast, $0.4 \mu \mathrm{M} H N T M B$ when complexed with $\mathrm{Cu}$ (II) was highly cytotoxic to the cells and exceeded toxicity of non-complexed $H N T M B$ (Fig. 7D, top panel). Remarkably, complexation of $H N T M B$ with $\mathrm{Fe}(\mathrm{III})$ fully prevented cytotoxicity of the compound. The viability of SKOV-3, OVCAR-3 and NUTU-19 compared to that of untreated controls or cells treated with the respective Fe (III) salt (Fig. 7D, bottom panel).

Following HNTMB treatment Western blotting confirmed the activation of effector caspase-7 and inactivation of PARP-1 (involved in DNA repair) in all three cell lines by $0.4 \mu \mathrm{M}$ of either non-complexed HNTMB or when complexed with $\mathrm{Cu}$ (II) (Fig. 7E). Apoptosis was not induced through $H N T M B$ when complexed with $\mathrm{Fe}$ (III) and expression levels of activated caspase- 7 and inactivated PARP-1 were similar to the controls (untreated cells or cells treated with $\mathrm{FeCl}_{3}$ or $\mathrm{CuCl}_{2}$ ) (Fig. 7E). Apoptosis was induced more rapidly by the copper-complex as compared to treatment with noncomplexed $H N T M B$ with a higher number of cells showing degradation (data not shown). In line with the kinetic study on the expression of apoptotic markers peaking at $24 \mathrm{~h}$ (Fig. 5) activation of caspase-7 or inactivation of PARP-1 at $48 \mathrm{~h}$ treatment with $\mathrm{Cu}(\mathrm{II}) /$ $H N T M B$ when compared to treatment with non-complexed $H N T M B$ was past the peak and less pronounced. However, the $48 \mathrm{~h}$ incubation was chosen to perform the Western Blotting analysis (Fig. 7E) in conjunction with our standardized Viability assay (48 $\mathrm{h}$ incubation; Fig. 7A, B, D) and ROS detection assay (Fig. 7C) all reveal that complexation of $H N T M B$ with copper but not with iron results in a potent drug to treat ovarian cancer cells.

\section{Discussion}

\section{Chelators in cancer treatment}

A low overall survival for advanced stages of ovarian cancer is related to the appearance of drug resistance to standard agents, notably organometallic platinum compounds. Research has been directed at the discovery of non-platinum chemotherapeutics with increased activity and response rates and among them chelating drugs and chelator metal complexes [7,41-44]. In addition, the efficacy of current anti-cancer drugs may be increased by combinational treatment with chelating drugs which have been shown to affect the metabolism and toxicity of anti-cancer compounds such as adriamycin, mitozantrone, bleomycin and hydroxyurea (HU) [7].

The objective of the present study was to investigate the potential of six different lipophilic aroylhydrazone chelators $(A H C)$ including novel compound $H N T M B$ as anti-tumor drugs and to analyze modes of action leading to cell death of ovarian cancer cells following HNTNB treatment. As a model system we choose OVCAR-3 cells resistant to clinically relevant concentrations of adriamycin, melphalan and cisplatin and SKOV-3 cells resistant to several cytotoxic drugs including cisplatin and adriamycin (see ATCC, Manassas, VA; http://www.atcc.org). To set the stage for potential future in vivo experiments using chelators in a syngenic rat tumor model [41] we included rat ovarian NUTU-19 cancer cell line in a screen for cytotoxicity by the various $A H C$ tested here.

\section{Efficacy of aroylhydrazone chelators in cancer cells}

Previous work showed that AHCs (often referred to as iron-chelators due to initial studies on high Fe chelation 
efficacy in cell lines and in vivo models) [45] exert antiproliferative and/or cytotoxic effects in neoplastic cells including cell lines derived from bladder carcinoma, rat hepatoma, T-cell leukemia, neuroblastoma, melanoma and leukemia [34,35,45-47]. To date no studies on the effect of $A H C$ compounds in ovarian cancer models, neither in vitro nor in vivo, have been published, and their mechanism of action leading to cell death remains unknown.

The present study shows that novel compound $H N T M B$ in its cytotoxic capacity $\left(\mathrm{IC}_{50}\right.$ between $200-400$ $\mathrm{nM}$ depending on the ovarian cancer cell line) is superior to other $A H C$ compounds (oVtBBH, HNtBBH, StBBH/206, HNTh2H/315 and HNI/311 and HNTMB) $\left(\mathrm{IC}_{50} 0.8-6 \mu \mathrm{M}\right)$ as well as to deferoxamine (DFO) $\left(\mathrm{IC}_{50}\right.$ 12-25 $\mu \mathrm{M}$ ) which was included as a reference. StBBH/ 206, HNTh2H/315 and HNI/311 in previous studies displayed anti-proliferative effects in neuroblastoma cell lines $\left(\mathrm{IC}_{50}=0.2-1.2 \mu \mathrm{M}\right)$, melanoma cells $\left(\mathrm{IC}_{50}\right.$ 0.8-1.0 $\mu \mathrm{M})$ and leukemia cells $\left(\mathrm{IC}_{50} 0.4-1.3 \mu \mathrm{M}\right)$ [34,35]. Two of the three AHC (HNTh2H/315 and HNI/311) and $H N T M B$ possess a 2-hydroxy-1-naphthylaldehyde moiety. The high lipophilicity of this aldehydic moiety when compared to $A H C$ compounds with a less lipophilic pyridoxal or salicylaldehyde group is correlated to increased anti-proliferative effects [34] and likely contributes to the effectiveness of the novel HNTMB studied here. $H N T M B$, apart from a hydroxy-1-naphthylaldehyde moiety and unlike the other structurally-related $A H C s$ studied here (HNI/311, HNTh2H/315, HNtBBH), possesses a trimethoxybenzene moiety, which is found in a large number of biologically active compounds, including anti-cancer drugs such as combretastatin. The trimethoxybenzene moiety in $H N T M B$ may be associated with the further improvement of its cytotoxicity in comparison to the structurally-related chelators without such a functional group. However, further studies must be conducted to prove whether this moiety is directly responsible for the high degree of cytotoxicity produced by $H N T M B$. The control compound DFO, structurally unrelated to $A H C s$, is a naturally occurring hexadentate iron-chelator that has been used as a therapeutic agent against ovarian [20] and other cancer cells [48-53]. However, the hydrophilic property of DFO limits its membrane-permeability and efficacy to target the intracellular trace metal pool including iron [54] or affect other intracellular processes. In contrast to DFO, compounds such as $H N T M B$ display a greater potency because of their better membrane-permeability profiles.

The observation to cytotoxic effects of $H N T M B$ on SKOV-3, OVCAR-3 and NUTU-19 ovarian cancer cells led to a screen performed by the NCI-DTP against a panel of cell lines http://dtp.nci.nih.gov/screening.html derived from human tumors of different origin. It became apparent that $H N T M B$ displayed potent cell line-specific but not tumor type-specific cytotoxicity with $\mathrm{GI}_{50}$ values in a 240 -fold range (between $10 \mathrm{nM}$ and $2.4 \mu \mathrm{M}$ depending on the cell line studied). Thus, cell death, depending on the target tumor or cancer cell line, can be induced by $H N T M B$ at concentrations in the nanomolar range. At these concentrations $A H C s$ may not exert their effects by critical depletion of the pool of intracellular iron but by binding to other trace metals such as copper (see discussion below). In vivo experiments have shown that effective treatment of tumors with related thiosemicarbazone $\mathrm{Dp} 44 \mathrm{mT}$, which reduced growth in melanoma xenografts in nude mice by $92 \%$, required low doses that did not cause iron depletion [55]. It is noteworthy that no direct correlation between the anti-proliferative activity of $A H C s$ with their abilities to prevent iron-uptake or mobilization in neuroblastoma cells was reported [34] suggesting that interference with iron metabolism may not be responsible for the effect of $A H C s$ on cell viability. Early studies examined the use of copper complexes of aroylhydrazone derivatives as therapeutic agents; $\mathrm{Cu}$ (II) complexation of SBH not only increased the compounds cytotoxicity but administration of this complex in mice was well tolerated [46]. The present study revealed that $H N T M B$ at $400 \mathrm{nM}$ when complexed with $\mathrm{Cu}(\mathrm{I})$ or $\mathrm{Cu}$ (II) displayed a high cytotoxicity correlated with massive generation of ROS. In contrast, HNTMB complexed with $\mathrm{Fe}(\mathrm{II})$ or $\mathrm{Fe}(\mathrm{III})$ lost its cytotoxicity and did not alter basal levels of ROS in SKOV-3 cells. Non-complexed $H N T M B$ displayed partial cytotoxicity and by binding to various trace metals is likely to disturb a multitude of functions important for cell proliferation and survival. HNTMB, as a tridentate coordinating ligand, has the ability to bind copper or iron in a stochiometric ratio of $1: 1$. Its IC50 determined for ovarian cancer cell lines is 200-400 $\mathrm{nM}(75-150 \mu \mathrm{g} / \mathrm{L})$ and the assay concentration of non-complexed HNTMB that we used was $150 \mu \mathrm{g} / \mathrm{L}$ which is a fraction of the total iron or copper content of cells. Ovarian cancer tissues contain 0.3-0.7 mg/kg copper and $15-17 \mathrm{mg} / \mathrm{kg}$ iron content [10]. By binding intracellular copper HNTMB can create a toxic ROSgenerating complex, while intracellular iron-chelation by $H N T M B$ depending on its concentration may lead to a variety of cellular consequences previously described for aroylhydrazone chelators [31]. These include ribonucleotide-reductase/RR inhibition, redox-activity leading to the hydroxylation of benzoate and the degradation of DNA in the presence of $\mathrm{Fe}(\mathrm{II})$ and $\mathrm{H}_{2} \mathrm{O}_{2}$, down-regulation of cell cycle regulators, and activation of WAF (mediator of p53 tumor suppression) among other genes.

Response mechanism of cancer cells to HNTMB treatment Through various experimental approaches the present study suggests that the mode of action of HNTMB in 
SKOV-3 cells relies on a variety of inter-dependent processes such as generation of ROS, DNA degradation, induction of apoptosis, and arrest of cell cycle progression through G2/M phase. ROS are generated in SKOV3 when treated with a copper/HNTMB complex but not when an iron/HNTMB complex was used. Thus, ROS generation observed after treatment with non-complexed $H N T M B$ is, at least, partially due to the drug binding intracellular copper (possibly by binding to other trace metals with a similar result). Production of ROS results in apoptosis and/or necrosis and can be used for selective targeting of tumor cells which possess higher oxidative stress level and display alteration of antioxidant enzymes (catalase, SOD) as compared to normal cells. Apparently, the $\mathrm{Cu} / H N T M B$ complex, as suggested for other chemotherapeutic drugs, may be used in oxidation therapy by elevating $\mathrm{H}_{2} \mathrm{O}_{2}$ and superoxide radical in tumor cells above the survival/death threshold (see introduction) $[17,56]$. Even though excess copper is known to be a potent oxidant causing the generation of ROS, we ruled out that unbound copper present in the sample of the $\mathrm{Cu} / H N T M B$ complex could be responsible for ROS generation. In controls, neither $\mathrm{Cu}$ (I) nor $\mathrm{Cu}(\mathrm{II})$ alone, at concentrations of $1.6 \mu \mathrm{M}$, resulted in cytotoxicity or ROS production during treatment. Previously, we determined that treatment with non-chelated copper does not affect the viability of ovarian cancer cell at or below a concentration of $30 \mu \mathrm{M}$ [41]. Therefore, we suggest that future studies should focus on the mechanistic responses of tumor cells to treatment with copper/AHCs complexes in general and specifically with a $\mathrm{Cu} / H N T M B$ complex in ovarian cancer models. The mechanism(s) by which the copperHNTMB complex generates elevated ROS levels remains under investigation but may include targeting of cellular thiol-containing anti-oxidant molecules such as glutathione (GSH) as this has been shown for other copper complexes such as CuNG [57]. Even upon treatment with non-complexed $H N T M B$ intracellular copper-chelation by $H N T M B$ might selectively be used to cause ROS-mediated cell death in certain tumors because a higher copper level is apparent both in serum and tumors of cancer patients including those suffering from breast and ovarian cancer [8-10]. Reference values determined by Yaman et al. [10] showed an average copper content in malignant ovarian tissue of $0.7 \mathrm{mg} / \mathrm{kg}$ copper versus $0.3 \mathrm{mg} / \mathrm{kg}$ in benign ovarian tissue. Interestingly, in these tissues the iron content for cancerous and noncancerous conditions is comparable (15-17 mg/kg) [10]. Thus, the iron/copper ratio decreases by a factor of 2 from benign to malignant ovarian tissues and may represent a target for chelation therapy.

In the present study, apart from ROS generation by ovarian cancer cells upon treatment with $H N T M B$, we observed other cellular responses of SKOV-3 cells to this chelator such as DNA degradation, arrest of cell cycle progression in $\mathrm{G} 2 / \mathrm{M}$ phase and activation of apoptotic signaling. Cell cycle regulation is known to be a target of chelating agents and has been attributed to the depletion of intracellular iron. Chelators of the $A H C$ class can regulate the expression of various proteins involved in cell-cycle control such as CDK2, cyclins A, $\mathrm{B} 1, \mathrm{D} 1, \mathrm{D} 2, \mathrm{D} 3$, WAF1 (inhibitor of CDKs) as shown for $\mathrm{HNI} / 311$ in neuroblastoma and an erythroleukemia cell line. While chelators such as $\mathrm{HNI} / 311$ or DFO generally block G1/S phase transition, effects on the G2/M transition during the cell cycle has also been implicated $[58,59]$. For DFO and a 3-hydroxypyridin-4-one ironchelator, it has been shown in K562 erythroleukemia cells that at higher concentrations these cells undergo arrest in G1/S while at lower drug concentrations they accumulated in $G 2$ and $M$ phase without an effect on DNA synthesis [60]. Thus, cell cycle regulation through iron-chelators may depend on the dose and the cell line studied. $H N T M B$ at $600 \mathrm{nM}$ lead to an accumulation of SKOV-3 primarily in G2/M phase. Future studies, beyond the scope of the present work, could focus on cell cycle checkpoints affected by HNTMB treatment in synchronized cancer cells and verify the general concept that iron-chelation (and not depletion of other intracellular metals) is responsible for these effects. Generally, targeting cell cycle key regulators has been suggested as a supplemental approach to anti-cancer therapies [61-64]. In addition, it is noteworthy that cells are most radiosensitive in the $\mathrm{G} 2 / \mathrm{M}$ phase [65]. Based on this and our findings, $H N T M B$ could be used as a radiosensitizer.

Drug treatment leading to programmed cell death (Apoptosis) results in the activation of initiator caspases which upon activation subsequently activate downstream effector caspases that are responsible for the cleavage of many intracellular proteins, leading to the morphological and biochemical changes associated with apoptosis $[66,67]$. HNTMB treatment of SKOV-3 cells resulted in strong activation/cleavage of initiator caspase- 8 and -9 and of effector caspase-3 and-7, while PARP-1 (involved in DNA repair) [68] was inactivated/cleaved following drug treatment. It is noteworthy that $H N T M B$ downregulated expression of the $\mathrm{X}$-linked inhibitor of apoptosis (XIAP). Down-regulation of XIAP expression in ovarian cancer cells results in apoptosis in vitro and prolonged survival of ovarian cancer-bearing mice, which indicate that XIAP may be a valuable therapeutic target in ovarian cancers [69]. Interestingly, cisplatinresistance in human ovarian surface epithelial (hOSE) cancer cells is correlated with the inability of cisplatin to down-regulate XIAP expression [70]. HNTMB may be an alternative apoptosis inducing drug in certain 
platinum-resistant cancers via XIAP reduction as shown to occur in SKOV-3 ovarian cancer cells used in the present study.

$H N T M B$ induced both major signaling pathways (intrinsic, extrinsic) as evidenced by the activation of initiator caspases similar to the effect of other iron chelators such as tachpyridine, DFO, and dipyridyl [71]. Intrinsic pathway activation may have mitochondrial damage as a pre-requisite, leading to the activation of pro-apoptotic members of the Bcl-2 family and/or inactivation of anti-apoptotic Bcl-2 and results in the mitochondrial release of cytochrome $\mathrm{C}$ which in turn activates initiator caspase-9 [72] as seen in SKOV-3 cells following $H N T M B$ treatment. It has previously been suggested that the mitochondrial pathway takes a center-role in iron chelator-mediated cell death since over-expression of anti-apoptotic Bcl-2 and Bcl-XL promotes cell (in HeLa cervix carcinoma cells) survival and chelator-mediated cell death can be blocked by a dominant-negative caspase 9 and Bcl-XL over-expression [71]. We show here that the exclusive down-regulation of Bcl-2 expression (in contrast to unmodified Bcl-XL or Bid) takes a center role in the pro-apoptotic response of SKOV-3 cells to treatment with $H N T M B$. Similarly, other $A H C$ compounds and their iron complexes cause apoptosis via the mitochondrial pathway (in Jurkat $\mathrm{T}$ cells and K562 leukemia) which could be counteracted by Bcl-2 overexpression [73]. Because anti-apoptotic Bcl-2 is highly expressed in various human cancers, this feature of $H N T M B$ increases its potential as an alternative anti-tumor drug. Bcl-2 also mediates the resistance of cancers to conventional therapies such as radio- and chemo-therapy. Thus, the blockage of Bcl-2 protein expression by $H N T M B$ treatment could be useful to sensitize cancer cells to conventional therapies [74]. A COMPARE analysis using the NCI's anticancer drug screen database suggested the involvement of Bcl-2 protein as a putative target of $H N T M B$. in its mechanism of action. The COMPARE computer program utilizes cytotoxicity data derived from screening compounds against 60 human cancer cell lines to calculate the Pearson correlation coefficient (positive correlation of 0.45 for $H N T M B)$, between the data for the seed compound and those for past agents in the database to identify similar molecular targets or similar mechanisms of resistance [75-79].

Induction of apoptosis by chelating agents, including representatives of $\mathrm{AHCs}$, has been primarily associated to their capability to bind/deplete intracellular iron [73]. These properties may be especially relevant for cancer treatment because (i) the intracellular concentration of iron is generally higher than that of copper and (ii) it can be significantly elevated in both serum and tumor tissue of cancer patients with endometrial or breast cancer $[9,10]$. The pro-apoptotic effects of non-complexed $H N T M B$ at higher concentrations may be partially linked to its capacity to bind/deplete intracellular iron. However, it is apparent that a copper/HNTMB complex at a concentration of $0.4 \mu \mathrm{l}$ strongly induces apoptosis, while an iron/HNTMB complex has no such effects. Observations related to the role of organocopper complexes in apoptotic events include disruption of the peroxide and thiol metabolism with subsequent up-regulation of pro-apoptotic Bcl-2 family members (Bak/Bax in melanoma and epithelial carcinoma cells) [80]. Previous studies have revealed that in the presence of complexed copper ( $\mathrm{Cu}-\mathrm{NTA}$ ) the expression of antiapoptotic Bcl-2 and Bcl-XL can be down-regulated (HL60 cells) [81]. Accordingly, the pro-apoptotic activity of $H N T M B$ may include direct effects on $\mathrm{Bcl}-2$ regulation when complexed with copper in contrast to the postulated indirect pro-apoptotic effects linked to intracellular iron depletion. We conclude that non-complexed $H N T M B$ exerts cytotoxicity on ovarian cancer cells in a dual function by binding copper $[\mathrm{Cu}(\mathrm{I})$ and $\mathrm{Cu}(\mathrm{II})]$ present in the human body [82] and the intracellular iron present in the Fe(II) and Fe(III) states [31].

\section{Conclusions}

The present report suggests that $H N T M B$ displays properties akin to an anti-cancer drug and could be an alternative to platinum derivatives in the treatment of ovarian cancer and other solid tumors. HNTMB can chelate iron and copper of different oxidation states and possess anti-cancer drug attributes via its properties as a chelator of intracellular trace-metals or, alternatively, as a cytotoxic organic metal- (e.g., copper) complex. $H N T M B$ and other chelating drugs of the lipophilic aroylhydrazone class may prove to be superior to other chelators or metal complexes already in use for the treatment of cancer. Experimental approaches using the ovarian cancer cell line SKOV-3 as a model system suggest various modes of action exerted by $H N T M B$ based on the generation of ROS, caspase activation, Bcl-2 down-regulation, DNA degradation and G2/M phase cell cycle arrest.

\section{List of abbreviations used}

AHC: aroylhydrazone chelators; DAPI: 4',6-diamidino-2phenylindole; DFO: deferoxamine; DMEM: Dulbecco's Modified Eagle's Medium; DMSO: dimethyl sulfoxide; FACS: fluorescence activated cell sorter; FL: fluorescein; H2DCFDA: 2',7'-dichlorodihydrofluorescein diacetate; MTS: 3-(4,5-dimethylthiazol-2-yl)-5-(3-carboxymethoxyphenyl)-2-(4-sulfophenyl)-2H-tetrazolium; NMR: nuclear magnetic resonance; PBS: phosphate buffered saline; ROS: reactive oxygen species; RR: ribonucleotide reductase; SOD: superoxide dismutase; TCA: trichloroacetic 
acid; TUNEL: terminal deoxynucleotidyl transferase dUTP nick end labeling.

\section{Acknowledgements}

This work was supported by an Ovarian Cancer Research Fund, Inc. (OCRF) Grant to Dr. Brard. The authors thank NIH COBRE Grant 1-P20RR018728 for providing instrumentation support.

\section{Author details}

${ }^{1}$ Molecular Therapeutics Laboratory, Program in Women's Oncology, Department of Obstetrics and Gynecology, Women and Infants' Hospital of Rl, Alpert Medical School of Brown University, Providence, RI 02905, USA. ${ }^{2}$ Division of Biology and Medicine, Brown University, Providence, RI 02912, USA.

\section{Authors' contributions}

KK and RKS performed the experimental procedures with support from TSL KK, TSL and LB were responsible for experimental design, interpretation of the results and writing the manuscript. All authors read and approved the final manuscript.

\section{Competing interests}

The authors declare that they have no competing interests.

\section{Received: 27 August 2009}

Accepted: 25 February 2010 Published: 25 February 2010

\section{References}

1. Heintz APM, Odicino F, Maisonneuve P, Beller U, Benedet JL, Creasman WT: International federation of gynecology and obstetrics 25 th annual report. carcinoma of the ovary. Int J Gyn Obst 2003, 83:135-137.

2. American Cancer Society. Cancer Facts and Figures 2008. http://www. cancer.org.

3. McGuire WP, Hoskins WJ, Brady MF, Kucera PR, Partridge EE, Look KY, Clarke-Pearson DL, Davidson M: Cyclophosphamide and cisplatin compared with paclitaxel and cisplatin in patients with stage III and stage IV ovarian cancer. N Engl I Med 1996, 334:1-6.

4. Piccart MJ, Bertelsen $\mathrm{K}$, James $\mathrm{K}$, Cassidy J, Mangioni C, Simonsen E, Stuart G, Kaye S, Vergote I, Blom R, Grimshaw R, Atkinson RJ, Swenerton KD, Trope C, Nardi M, Kaern J, Tumolo S, Timmers P, Roy JA, Lhoas F, Lindvall B, Bacon M, Birt A, Andersen JE, Zee B, Paul J, Baron B, Pecorelli S: Randomized intergroup trial of cisplatin-paclitaxel versus cisplatincyclophosphamide in women with advanced epithelial ovarian cancer: three-year results. J Natl Cancer Inst 2000, 92:699-708.

5. Leitao MM Jr, Hummer A, Dizon DS, Aghajanian C, Hensley M, Sabbatini P, Venkatraman E, Spriggs DR: Platinum-retreatment of platinum-resistant ovarian cancer after nonplatinum therapy. Gynecol Oncol 2003, 91:123-129.

6. Lamberth E, Gregory WM, Nelstrop AE, Rustin GJ: Long-term survival in 463 women treated with platinum analogs for advanced epithelial carcinoma of the ovary: life expectancy compared to women of an agematched normal population. Int J Gynecol Cancer 2004, 14:772-778.

7. Kontoghiorghes GJ, Efstathiou A, loannou Loucaides S, Kolnagou A: Chelators controlling metal metabolism and toxicity pathways: applications in cancer prevention, diagnosis and treatment. Hemoglobin 2008, 32:217-227.

8. Chan A, Wong F, Arumanayagam M: Serum ultrafiltrable copper, total copper and ceruloplasmin concentrations in gynecological carcinoma. Ann Clin Biochem 1993, 30:545-549.

9. Kuo KW, Chen SF, Wu CC, Chen DR, Lee JH: Serum and tissue trace elements in patients with breast cancer in Taiwan. Biol Trace Elem Res 2002, 89:1-11.

10. Yaman M, Kaya G, Simsek M: Comparison of trace element concentrations in cancerous and non cancerous human endometrial and ovary tissues. Int J Gynecol Cancer 2007, 17:220-228.

11. Daniel KG, Chen D, Orlu S, Cui QC, Miller FR, Dou QP: Clioquinol and pyrrolidine dithiocarbamate complex with copper to form proteasome inhibitors and apoptosis inducers in human breast cancer cells. Breast Cancer Res 2005, 7:R897-R908.
12. Gupte A, Mumper RJ: Copper chelation by D-penicillamine generates reactive oxygen species that are cytotoxic to human leukemia and breast cancer cells. Free Radic Biol Med 2007, 43:1271-1278.

13. Linder MC, Hazegh-Azam M: Copper biochemistry and molecular biology. Am J Clin Nutrition 1996, 63:797S-811S.

14. Yu Y, Wong J, Lovejoy DB, Kalinowski DS, Richardson DR: Chelators at the cancer coalface: desferrioxamine to Triapine and beyond. Clin Cancer Res 2006, 12:6876-6883.

15. Gomes A, Fernandes E, Lima JLFC: Fluorescence probes used for detection of reactive oxygen species. J Biochem Biophys Methods 2005 65:45-80.

16. Waris $G$, Ahsan HJ: Reactive oxygen species: role in the development of cancer and various chronic conditions. Carcinog 2006, 5:1-8.

17. Gupte A, Mumper RJ: Elevated copper and oxidative stress in cancer cells as a target for cancer treatment. Cancer Treat Rev 2009, 35:32-46.

18. Hileman EO, Liu J, Albitar M, Keating MJ, Huang P: Intrinsic oxidative stress in cancer cells: a biochemical basis for therapeutic selectivity. Cancer Chemother Pharmacol 2004, 53:209-219.

19. Pelicano H, Carney D, Huang P: ROS stress in cancer cells and therapeutic implications. Drug Resistance Updat 2004, 7:97-110.

20. Brard L, Granai CO, Swamy N: Iron chelators deferoxamine and diethylenetriamine pentaacetic acid induce apoptosis in ovarian carcinoma. Gynecol Oncol 2006, 100:116-127.

21. Neufeld EJ: Oral chelators deferasirox and deferiprone for transfusional iron overload in thalassemia major: new data, new questions. Blood 2006, 107:3436-3441.

22. Turner J, Koumenis C, Kute TE, Planalp RP, Brechbiel MW, Beardsley D, Cody B, Brown KD, Torti FM, Torti S: Tachpyridine, a metal chelator, induces G2 cell cycle arrest, activates checkpoint kinases, and sensitizes cells to ionizing radiation. Blood 2005, 106:3191-3199.

23. Liu MC, Lin TS, Sartorelli AC, Liu MC, Lin TS, Sartorelli AC: Synthesis and anti-tumor activity of amino derivatives of pyridine-2-carboxaldehyde thiosemicarbazone. J Med Chem 1992, 35:3672-3677.

24. Rakba N, Loyer P, Gilot D, Delcros JG, Glaise D, Baret P, Pierre JL, Brissot P, Lescoat G: Antiproliferative and apoptotic effects of O-Trensox, a new synthetic iron-chelator, on differentiated human hepatoma cell lines. Carcinogenesis 2000, 21:943-951.

25. Crichton RR, Ward RJ: Iron metabolism-new perspectives in view. Biochemistry 1992, 31:11255-11264.

26. Huang $X$ : Iron overload and its association with cancer risk in humans: evidence for iron as a carcinogenic metal. Mutation Res 2003, 533:153-171.

27. Toyokuni S: Iron-induced carcinogenesis: the role of redox regulation. Free Radical Biol Med 1996, 20:553-566.

28. Faulk WP, Hsi B, Stevens PJ: Transferrin and transferrin receptors in carcinoma of the breast. Lancet 1980, 23:390-392.

29. Seymour GJ, Walsh MD, Lavin MF, Strutton G, Gardiner RA: Transferrin receptor expression by human bladder transitional cell carcinomas. Urol Res 1987, 15:341-344.

30. Fassl $\mathrm{S}$, Leisser $C$, Huettenbrenner $S$, Maier $S$, Rosenberger $G$, Strasser $S$, Grusch M, Fuhrmann G, Leuhuber K, Polgar D, Stani J, Tichy B, Nowotny C, Krupitza G: Transferrin ensures survival of ovarian carcinoma cells when apoptosis is induced by TNFalpha, FasL, TRAIL, or Myc. Oncogene 2003, 22:8343-8355.

31. Richardson DR, Kalinowski DS, Lau S, Jansson PJ, Lovejoy DB: Cancer cell iron metabolism and the development of potent iron chelators as antitumor agents. Biochim Biophys Acta 2009, 1790:702-717.

32. Melnyk P, Leroux V, Sergheraert C, Grellier P: Design, synthesis and in vitro antimalarial activity of an acylhydrazone library. Bioorg Med Chem Lett 2006, 16:31-35.

33. Baker $E$, Richardson DR, Gross S, Ponka P: Evaluation of the iron chelation potential of hydrazones of pyridoxal, salicylaldehyde and 2-hydroxy-1naphthylaldehyde using the hepatocyte in culture. Hepatology 1992, 15:492-501.

34. Richardson DR, Tran EH, Ponka P: The potential of iron chelators of the pyridoxal isonicotinoyl hydrazone class as effective antiproliferative agents. Blood 1995, 86:4295-4306.

35. Richardson DR, Milnes $K$ : The potential of iron-chelators of the pyridoxal isonicotinoyl hydrazone class as effective antiproliferative agents II: the mechanism of action of ligands derived from salicylaldehyde benzoyl hydrazone and 2-hydroxy-1-naphthylaldehyde benzoyl hydrazone. Blood 1997, 89:3025-3038. 
36. Rose GS, Tocco LM, Grange GA, DiSaia PJ, Hamilton TC, Santin AD, Hiserodt JC: Development and characterization of a clinically useful animal model of epithelial ovarian cancer in the Fischer 344 rat. Am J Obstet Gynecol 1996, 175:593-599.

37. Malich G, Markovic B, Winder C: The sensitivity and specificity of the MTS tetrazolium assay for detecting the in vitro cytotoxicity of 20 chemicals using human cell lines. Toxicol 1997, 124:179-192.

38. Singh RK, Lange TS, Shaw SK, Kim KK, Brard L: A novel Indole Ethyl Isothiocyanate (7Me-IEITC) with anti-proliferative and pro-apoptotic effects on platinum-resistant human ovarian cancer cells. Gynecol Oncol 2008, 109:240-249.

39. Lange TS, Singh RK, Kim KK, Zou Y, Kalkunte SS, Sholler GL, Swamy N, Brard L: Anti-proliferative and pro-apoptotic properties of 3bromoacetoxy calcidiol (B3CD) in high-risk neuroblastoma. Chem Biol Drug Design 2007, 70:302-310.

40. Gorczyca W, Gong J, Darzynkiewicz Z: Detection of DNA strand breaks in individual apoptotic cells by the in situ terminal deoxynucleotidyl transferase and nick translation assays. Cancer Res 1993, 53:1945-1951.

41. Lange TS, Carolyn McCourt C, Singh RK, Kim KK, Singh AP, Luisi BS, Strongin RM, Brard L: Apoptotic and chemotherapeutic properties of iron (III) salophene in an ovarian cancer animal model. Drug Design, Development and Therapy 2008, 3:17-26.

42. Ott I, Gust R: Non platinum metal complexes as anti cancer drugs. Arch Pharm 2007, 340:117-126.

43. Huang R, Wallquist A, Covell DG: Anticancer metal compounds in $\mathrm{NCl}$ s tumor screening database: putative mode of action. Biochem Pharmacol 2005, 69:1009-1039.

44. Lange TS, Kim KK, Singh RK, Strongin RM, McCourt CK, Brard L: Iron(III)salophene: An metallo-organic compound with selective cytotoxic and anti-proliferative properties in platinum-resistant ovarian cancer cells. PLOS One 2008, 3(e2303):1-10.

45. Richardson DR, Bernhardt PV: Crystal and molecular structure of 2 hydroxy 1 naphthaldehyde isonicotinoyl hydrazone $(\mathrm{NIH})$ and its iron (III) complexes: an iron chelator with anti tumour activity. J Biol Inorg Chem 1999, 4:266-273.

46. Johnson DK, Murphy TB, Rose NJ: Cytotoxic chelators and chelates 1. Inhibition of DNA synthesis in cultured rodent and human cells by AHCs and by a copper(II) complex of salicyladehyde benzoyl hydrazone. Inorganica Chim Acta 1982, 67:159-165.

47. Koha LL, Konb OL, Loha KW, Longa YC, Ranforda JD, Tanc ALC, Tjana YY: Complexes of salicylaldehyde acylhydrazones: Cytotoxicity, QSAR and crystal structure of the sterically hindered t butyl dimer. J Inorg Biochem 1998, 72:155-162.

48. Haq RU, Wereley JP, Chitambar CR: Induction of apoptosis by iron deprivation in human leukemic CCRF-CEM cells. Exp Hematol 1995, 23:428-432.

49. Blastt J, Stitely S: Antineuroblastoma activity of desferrioxamine in human cell lines. Cancer Res 1987, 47:1749-1750.

50. Simonart T, Degraef $C$, Andrei G, Mosselmans R, Hermans P, Van Vooren JP, Noel JC, Boelaert JR, Snoeck R, Heenen M: Iron chelators inhibit the growth and induce the apoptosis of Kaposi's sarcoma cells and of their putative endothelial precursors. J Invest Dermatol 2000, 115:893-900.

51. Hoke EM, Maylock CA, Shacter E: Desferal inhibits breast tumor growth and does not interfere with the tumoricidal activity of doxorubicin. Free Radic Biol Med 2005, 39:403-411.

52. Richardson DR, Ponka P, Baker E: The effect of the iron(III) chelator, desferrioxamine, on iron and transferrin uptake by the human malignant melanoma cell. Cancer Res 1994, 54:685-689.

53. Hann HW, Stahlhut MW, Hann CL: Effect of iron and desferoxamine on cell growth and in vitro ferritin synthesis in human hepatoma cell lines. Hepatology 1990, 11:566-569.

54. Hoffbrand AV: Prospects for oral iron chelation therapy. J Lab Clin Med 1994, 123:492-494

55. Whitnall $M$, Howard J, Ponka P, Richardson DR: A class of iron chelators with a wide spectrum of potent antitumor activity that overcomes resistance to chemotherapeutics. PNAS 2006, 103:14901-14906.

56. Renschler MF: The emerging role of reactive oxygen species in cancer therapy. Eur J Cancer 2004, 40:1934-1940.

57. Mookerjee A, Basu JM, Majumder S, Chatterjee S, Panda GS, Dutta P, Pal S, Mukherjee P, Efferth T, Roy S, Choudhuri SK: A novel copper complex induces ROS generation in doxorubicin resistant Ehrlich ascitis carcinoma cells and increases activity of antioxidant enzymes in vital organs in vivo. BMC Cancer 2006, 6, article\#267.

58. Gao J, Richardson DR: Multiple effects of iron chelators on molecules controlling cell cycle progression. J Transfusion Sci 2000, 23:247-248.

59. Gao J, Richardson DR: The potential of iron chelators of the pyridoxal isonicotinoyl hydrazone class as effective antiproliferative agents, IV: The mechanisms involved in inhibiting cell-cycle progression. Blood 2001, 98:842-850.

60. Hoyes KP, Hider RC, Porter JB: Cell cycle synchronization and growth inhibition by 3 hydroxypyridin 4 one iron chelators in leukemia cell lines. Cancer Res 1992, 52:4591-4599.

61. Hartwell LH, Kastan MB: Cell-cycle control and cancer. Science 1994, 266:1821-1828.

62. Gladden $A B$, Diehl JA: Cell cycle progression without cyclin E/CDK2: breaking down the walls of dogma. Cancer Cell 2003, 4:160-162.

63. Shapiro Gl, Harper JW: Anticancer drug targets: cell cycle and checkpoint control. J Clin Invest 1999, 104:1645-1653.

64. Mazumder S, DuPree EL, Almasan A: A dual role of cyclin E in cell proliferation and apoptosis may provide a target for cancer therapy. Curr Cancer Drug Targets 2004, 4:65-75.

65. Pawlik TM, Keyomarsi K: Role of cell cycle in mediating sensitivity to radiotherapy. Int J Radiat Oncol Biol Phys 2004, 59:928-942.

66. Salvesen GS, Abrams JM: Caspase activation stepping on the gas or releasing the brakes? Lessons from humans and flies. Oncogene 2004, 23:2774-27784.

67. Thornberry NA, Lazebnik Y: Caspases: enemies within. Science 1998, 281:1312-1316.

68. Oliver FJ, de la Rubia G, Rolli V, Ruiz Ruiz MC, de Murcia G, Murcia JM: Importance of poly(ADP ribose) polymerase and its cleavage in apoptosis. Lesson from an uncleavable mutant. J Biol Chem 1998, 73:33533-33539.

69. Shaw TJ, Lacasse EC, Durkin JP, Vanderhyden BC: Downregulation of XIAP expression in ovarian cancer cells induces cell death in vitro and in vivo. Int J Cancer 2008, 122:1430-1434.

70. Li J, Feng Q, Kim JM, Schneiderman D, Liston P, Li M, Vanderhyden B, Faught W, Fung MF, Senterman M, Korneluk RG, Tsang BK: Human ovarian cancer and cisplatin resistance: possible role of inhibitor of apoptosis proteins. Endocrinology 2001, 142:370-380.

71. Greene BT, Thorburn J, Willingham MC, Thorburn A, Planalp RP, Brechbiel MW, Jennings Gee J, Wilkinson J, Torti FM, Torti SV: Activation of caspase pathways during iron chelator mediated apoptosis. J Biol Chem 2002, 277:25568-25575.

72. Putcha GV, Harris CA, Moulder KL, Easton RM, Thompson CB, Johnson EM: Intrinsic and extrinsic pathway signaling during neuronal apoptosis: lessons from the analysis of mutant mice. I Cell Biol 2002, 157:441-453.

73. Bussa JL, Neuzilb J, Gellertc N, Weber C, Ponka P: Pyridoxal isonicotinoyl hydrazone analogs induce apoptosis in hematopoietic cells due to their iron-chelating properties. Biochem Pharmacol 2003, 65:161-172.

74. Huang $\mathrm{Z}$ : $\mathrm{BCl} 2$ family proteins as targets for anticancer drug design. Oncogene 2000, 19:6627-6631.

75. Paull KD, Shoemaker RH, Hodes L, Monks A, Scudiero DA, Rubinstein L, Plowman J, Boyd MR: Display and analysis of pattern of differential activity of drugs against human tumor cell lines: development of mean graph and COMPARE algorithm. J Natl Cancer Inst 1989, 81:1088-1092.

76. Weinstein JN, Kohn KW, Grever MR, Viswanadhan VN, Rubinstein LV, Monks AP, Scudiero DA, Welch L, Koutsoukos AD, Chiausa AJ: Neural computing in cancer drug development: predicting mechanism of action. Science 1992, 258:447-451.

77. Boyd MR, Paull KD: Some practical considerations and applications of the National Cancer Institute in vivo anticancer drug discovery screen. Drug Dev Res 1995, 34:91-109.

78. Bates SE, Fojo AT, Weinstein JN, Myers TG, Alvarez M, Pauli KD, Chabner BA: Molecular targets in the National Cancer Institute drug screen. J Cancer Res Clin Oncol 1995, 121:495-500.

79. Weinstein JN, Myers TG, O'Connor PM, Friend SH, Fornace A Jr, Kohn KW, Fojo T, Bates SE, Rubinstein LV, Anderson NL, Buolamwini JK, van Osdol WW, Monks AP, Scudiero DA, Sausville EA, Zaharevitz DW, Bunow B, Viswanadhan VN, Johnson GS, Wittes RE, Paull KD: An information intensive approach to the molecular pharmacology of cancer. Science 1997, 275:343-349 
80. Viola Rhenals M, Rieber MS, Rieber M: Role of peroxidases, thiols and Bak/ Bax in tumor cell susceptibility to Cu[DEDTC]2. Biochem Pharmacol 2007, 74:841-850.

81. Ma Y, Cao L, Kawabata T, Yoshino T, Yang BB, Okada S: Cupric nitrilotriacetate induces oxidative DNA damage and apoptosis in human leukemia HL-60 cells. Free Radic Biol Med 1998, 25:568-575.

82. Harris ZH, Gitlin JD: Genetic and molecular basis of copper toxicity. Am J Clin Nutr 1996, 63:8365-841S.

\section{Pre-publication history}

The pre-publication history for this paper can be accessed here:http://www. biomedcentral.com/1471-2407/10/72/prepub

doi:10.1186/1471-2407-10-72

Cite this article as: Kim et al:: Lipophilic aroylhydrazone chelator HNTMB and its multiple effects on ovarian cancer cells. BMC Cancer 2010 10:72.

\section{Submit your next manuscript to BioMed Central} and take full advantage of:

- Convenient online submission

- Thorough peer review

- No space constraints or color figure charges

- Immediate publication on acceptance

- Inclusion in PubMed, CAS, Scopus and Google Scholar

- Research which is freely available for redistribution

Submit your manuscript at www.biomedcentral.com/submit 